\title{
LEVEL II SCOUR ANALYSIS FOR BRIDGE 41 (ROCKTH00390041) on TOWN HIGHWAY 39, crossing the SAXTONS RIVER, ROCKINGHAM, VERMONT
}

U.S. Geological Survey

Open-File Report 97-377

Prepared in cooperation with

VERMONT AGENCY OF TRANSPORTATION

and

FEDERAL HIGHWAY ADMINISTRATION 


\section{LEVEL II SCOUR ANALYSIS FOR BRIDGE 41 (ROCKTH00390041) on TOWN HIGHWAY 39, crossing the SAXTONS RIVER, ROCKINGHAM, VERMONT}

By Erick M. Boehmler and James R. Degnan

U.S. Geological Survey Open-File Report 97-377

Prepared in cooperation with

VERMONT AGENCY OF TRANSPORTATION

and

FEDERAL HIGHWAY ADMINISTRATION 


\title{
U.S. DEPARTMENT OF THE INTERIOR BRUCE BABBITT, Secretary
}

\author{
U.S. GEOLOGICAL SURVEY \\ Gordon P. Eaton, Director
}

For additional information write to:

District Chief

U.S. Geological Survey 361 Commerce Way

Pembroke, NH 03275-3718
Copies of this report may be purchased from:

U.S. Geological Survey

Branch of Information Services

Open-File Reports Unit

Box 25286

Denver, CO 80225-0286 


\section{CONTENTS}

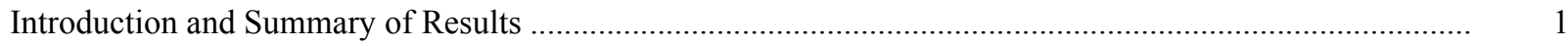

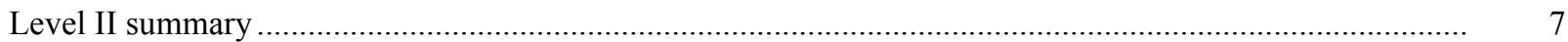

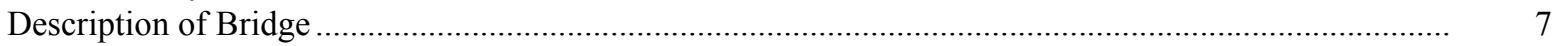

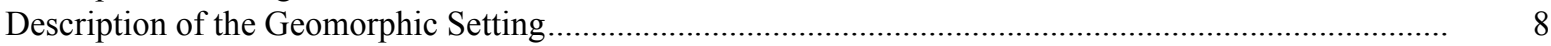

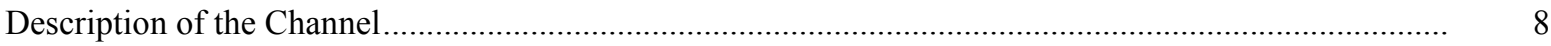

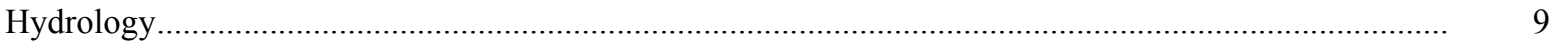

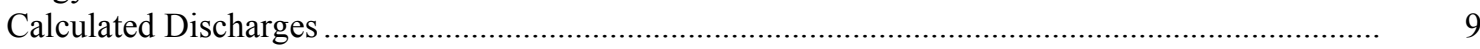

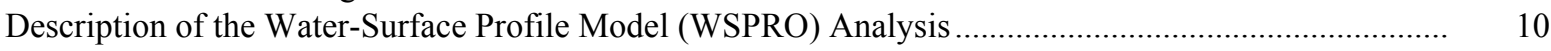

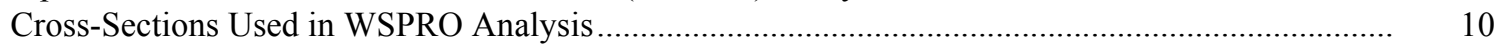

Data and Assumptions Used in WSPRO Model ...................................................................... 11

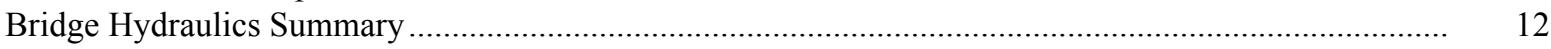

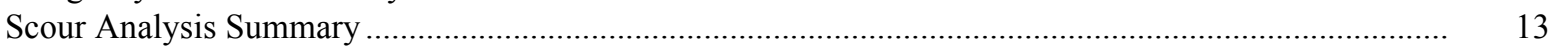

Special Conditions or Assumptions Made in Scour Analysis ...................................................... 13

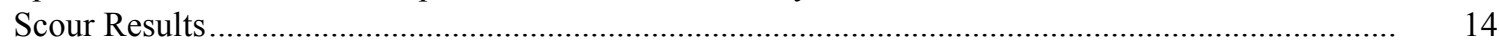

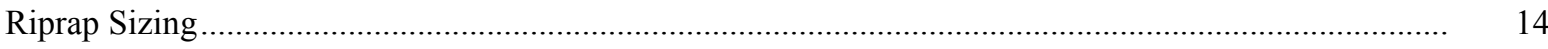

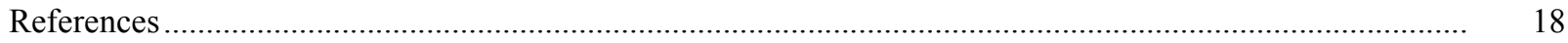

Appendixes:

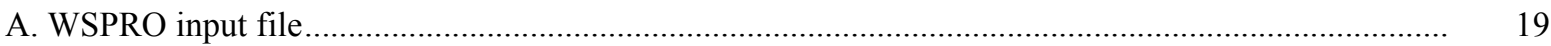

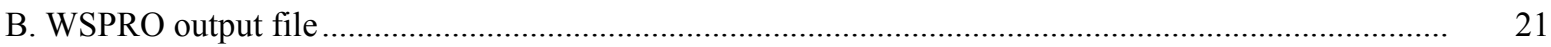

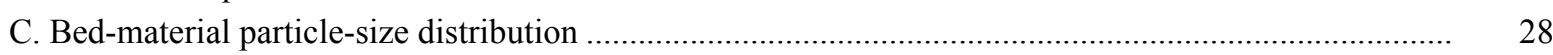

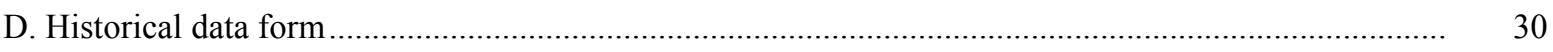

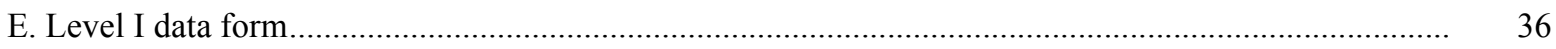

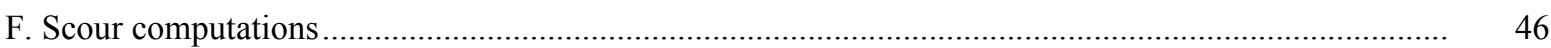

\section{FIGURES}

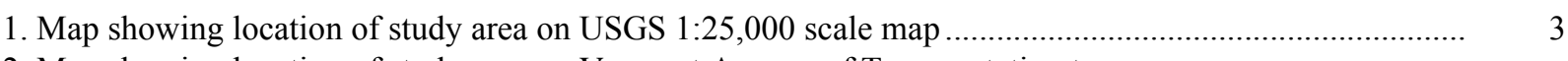

2. Map showing location of study area on Vermont Agency of Transportation town
highway map

3. Structure ROCKTH00390041 viewed from upstream (August 15, 1996) ............................................. 5

4. Downstream channel viewed from structure ROCKTH00390041 (August 15, 1996)............................ 5

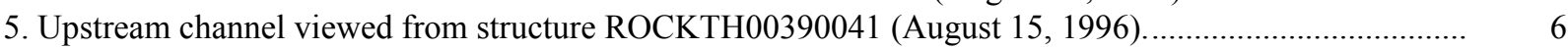

6. Structure ROCKTH00390041 viewed from downstream (August 15, 1996). ....................................... 6

7. Water-surface profiles for the 100- and 500-year discharges at structure

ROCKTH00390041 on Town Highway 39, crossing Saxtons River,

Rockingham, Vermont.

8. Scour elevations for the 100- and 500-year discharges at structure

ROCKTH00390041 on Town Highway 39, crossing Saxtons River,

Rockingham, Vermont.

\section{TABLES}

1. Remaining footing/pile depth at abutments for the 100-year discharge at structure

ROCKTH00390041 on Town Highway 39, crossing Saxtons River,

Rockingham, Vermont

2. Remaining footing/pile depth at abutments for the 500-year discharge at structure

ROCKTH00390041 on Town Highway 39, crossing Saxtons River,

Rockingham, Vermont..... 


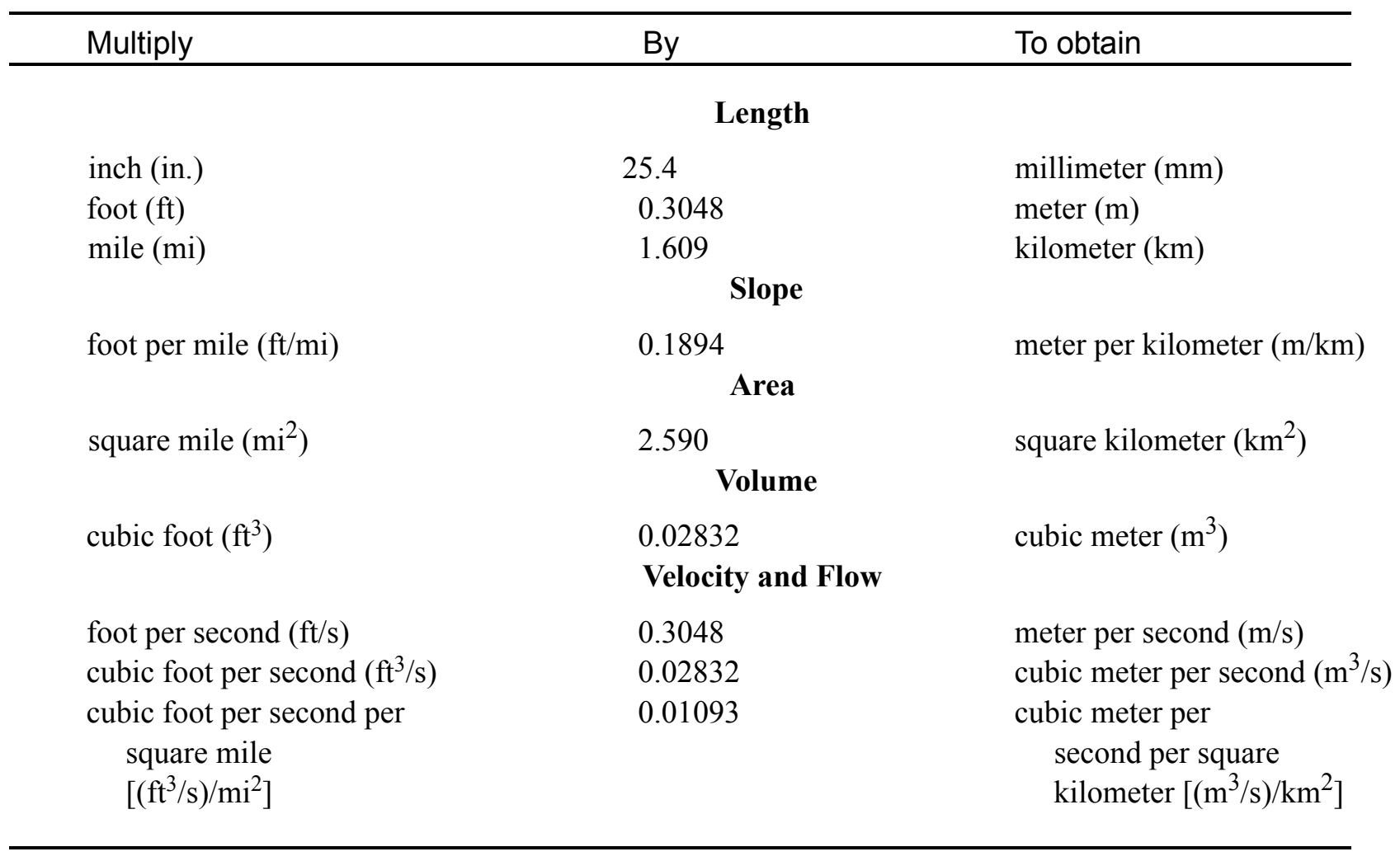

\section{OTHER ABBREVIATIONS}

$\begin{array}{lrlr}\mathrm{BF} & \text { bank full } & \text { LWW } & \text { left wingwall } \\ \mathrm{cfs} & \text { cubic feet per second } & \text { MC } & \text { main channel } \\ \mathrm{D}_{50} & \text { median diameter of bed material } & \text { RAB } & \text { right abutment } \\ \mathrm{DS} & \text { downstream } & \text { RABUT } & \text { face of right abutment } \\ \mathrm{elev} & \text { elevation } & \text { RB } & \text { right bank } \\ \mathrm{f} / \mathrm{p} & \text { flood plain } & \text { ROB } & \text { right overbank } \\ \mathrm{ft}^{2} & \text { square feet } & \text { RWW } & \text { right wingwall } \\ \mathrm{ft} / \mathrm{ft} & \text { feet per foot } & \text { TH } & \text { town highway } \\ \mathrm{JCT} & \text { junction } & \text { UB } & \text { under bridge } \\ \mathrm{LAB} & \text { left abutment } & \text { US } & \text { upstream } \\ \mathrm{LABUT} & \text { face of left abutment } & \text { USGS } & \text { United States Geological Survey } \\ \mathrm{LB} & \text { left bank } & \text { VTAOT Vermont Agency of Transportation } \\ \mathrm{LOB} & \text { left overbank } & \text { WSPRO } & \text { water-surface profile model }\end{array}$

In this report, the words "right" and "left" refer to directions that would be reported by an observer facing downstream. Sea level: In this report, "sea level" refers to the National Geodetic Vertical Datum of 1929-- a geodetic datum derived from a general adjustment of the first-order level nets of the United States and Canada, formerly called Sea Level Datum of 1929.

In the appendices, the above abbreviations may be combined. For example, USLB would represent upstream left bank. 


\title{
LEVEL II SCOUR ANALYSIS FOR BRIDGE 41 (ROCKTH00390041) ON TOWN HIGHWAY 39, CROSSING THE SAXTONS RIVER, ROCKINGHAM, VERMONT
}

\author{
By Erick M. Boehmler and James R. Degnan
}

\section{INTRODUCTION AND SUMMARY OF RESULTS}

This report provides the results of a detailed Level II analysis of scour potential at structure ROCKTH00390041 on Town Highway 39 crossing the Saxtons River, Rockingham, Vermont (figures 1-8). A Level II study is a basic engineering analysis of the site, including a quantitative analysis of stream stability and scour (U.S. Department of Transportation, 1993). Results of a Level I scour investigation also are included in Appendix E of this report. A Level I investigation provides a qualitative geomorphic characterization of the study site. Information on the bridge, gleaned from Vermont Agency of Transportation (VTAOT) files, was compiled prior to conducting Level I and Level II analyses and is found in Appendix D.

The site is in the New England Upland section of the New England physiographic province in southeastern Vermont. The 57.4- $\mathrm{mi}^{2}$ drainage area is in a predominantly rural and forested basin. In the vicinity of the study site, the surface cover consists of forest on the left bank and pasture with some trees on the right bank.

In the study area, the Saxtons River has an sinuous channel with a slope of approximately $0.009 \mathrm{ft} / \mathrm{ft}$, an average channel top width of $112 \mathrm{ft}$ and an average bank height of $10 \mathrm{ft}$. The channel bed material ranges from sand to cobbles with a median grain size $\left(D_{50}\right)$ of $103 \mathrm{~mm}$ $(0.339 \mathrm{ft})$. The geomorphic assessment at the time of the Level I and Level II site visit on August 15, 1996, indicated that the reach was laterally unstable. There are wide point bars, cut-banks with fallen trees, and areas of localized channel scour along the left bank, where there is bedrock exposure at the surface.

The Town Highway 39 crossing of the Saxtons River is an 85-ft-long, one-lane bridge consisting of one 82-foot steel-beam span (Vermont Agency of Transportation, written communication, March 31, 1995). The bridge is supported by vertical, concrete abutments without wingwalls. The channel is skewed approximately 30 degrees to the opening while the opening-skew-to-roadway is zero degrees. 
A scour hole $3 \mathrm{ft}$ deeper than the mean thalweg depth was observed during the Level I assessment along the left side of the channel under the bridge exposing the left abutment footing 5.5 feet. The only scour protection measure at the site was type- 2 stone fill (less than 36 inches diameter) on the left banks upstream and downstream and the left abutment wall. Additional details describing conditions at the site are included in the Level II Summary and Appendices D and E.

Scour depths and recommended rock rip-rap sizes were computed using the general guidelines described in Hydraulic Engineering Circular 18 (Richardson and others, 1995). Total scour at a highway crossing is comprised of three components: 1) long-term streambed degradation; 2) contraction scour (due to accelerated flow caused by a reduction in flow area at a bridge) and; 3 ) local scour (caused by accelerated flow around piers and abutments). Total scour is the sum of the three components. Equations are available to compute depths for contraction and local scour and a summary of the results of these computations follows.

Contraction scour for all modelled flows ranged from 2.2 to 3.8 feet. The worst-case contraction scour occurred at the 500-year discharge. Abutment scour ranged from 21.4 to 23.2 feet and 26.2 to 32.4 feet at the left and right abutments respectively. The worst-case abutment scour occurred for the right abutment at the incipient overtopping discharge. Additional information on scour depths and depths to armoring are included in the section titled "Scour Results". Scoured-streambed elevations, based on the calculated scour depths, are presented in tables 1 and 2. A cross-section of the scour computed at the bridge is presented in figure 8. Bedrock was exposed at the surface in some areas of the channel and potentially is located at a shallower depth than the scour depths indicated above.

Nevertheless, scour depths were calculated assuming an infinite depth of erosive material and a homogeneous particle-size distribution.

It is generally accepted that the Froehlich equation (abutment scour) gives "excessively conservative estimates of scour depths" (Richardson and others, 1995, p. 47). Usually, computed scour depths are evaluated in combination with other information including (but not limited to) historical performance during flood events, the geomorphic stability assessment, existing scour protection measures, and the results of the hydraulic analyses. Therefore, scour depths adopted by VTAOT may differ from the computed values documented herein. 


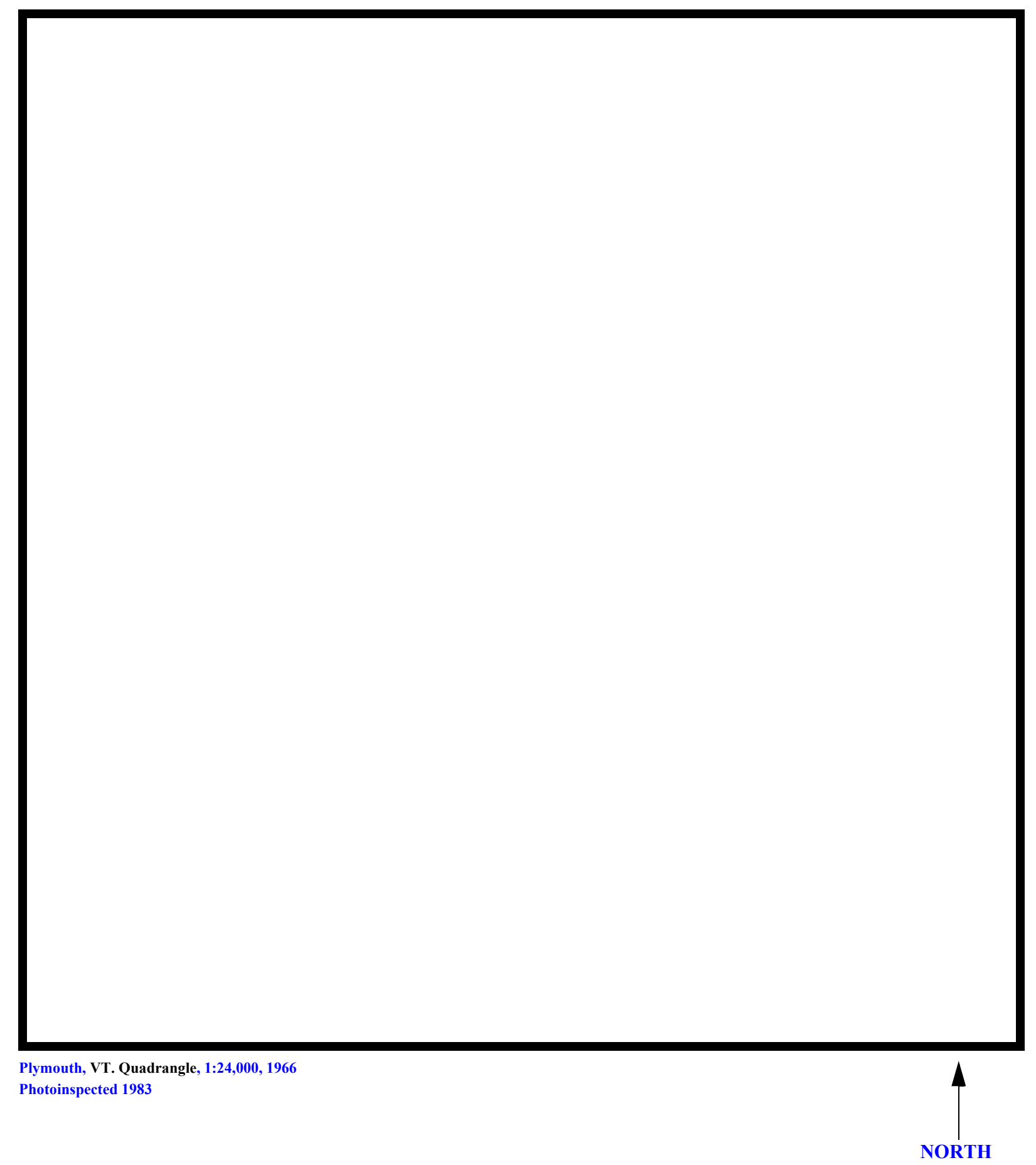

Figure 1. Location of study area on USGS 1:24,000 scale map. 
Figure 2. Location of study area on Vermont Agency of Transportation town highway map. 

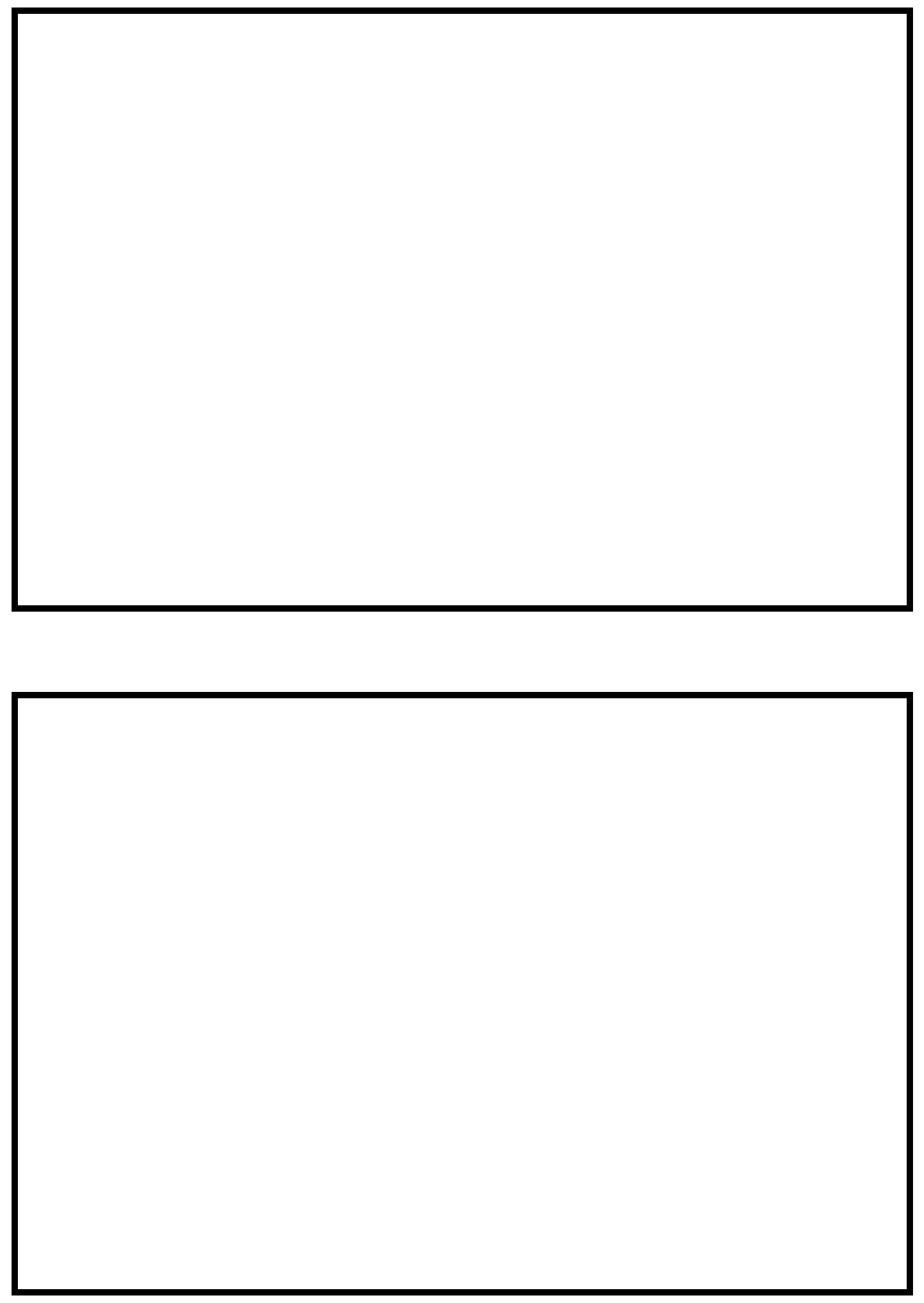

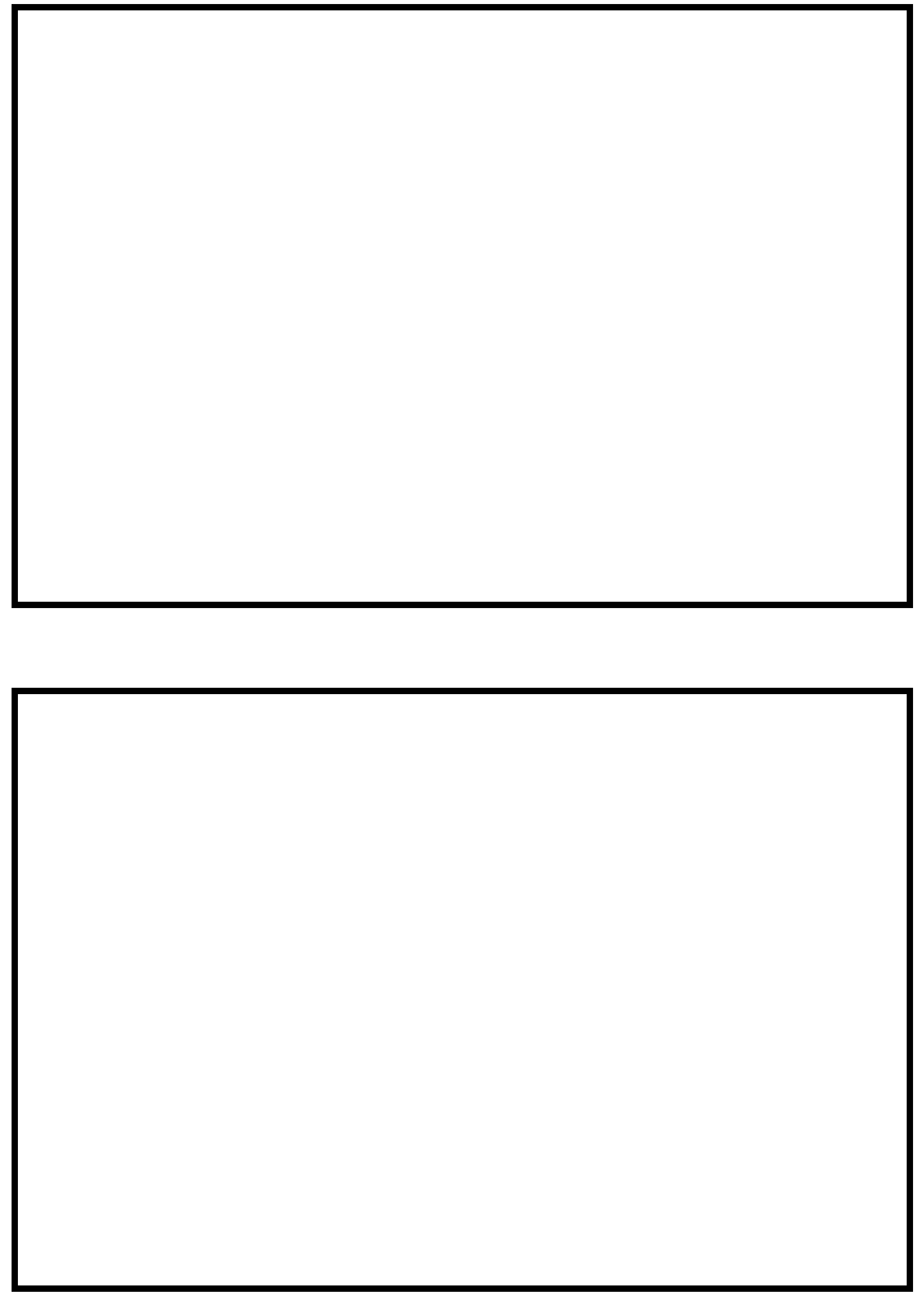


\section{Description of the Geomorphic Setting}

General topography The channel is located in a moderate relief valley setting with narrow, irregular overbank areas and steep valley walls on both sides.

Geomorphic conditions at bridge site: downstream (DS), upstream (US)

Date of inspection $\quad 8 / 15 / 96$

DS left: $\quad$ Steep channel bank to VT 121 roadway surface.

DS right: $\quad$ Mildly sloping channel bank to a narrow overbank.

US left: $\quad$ Steep channel bank to VT 121 roadway surface.

US right: $\quad$ Mildly sloping channel bank to a narrow overbank.

\section{Description of the Channel}

\begin{tabular}{|c|c|c|c|}
\hline \multirow[b]{2}{*}{ Average top width } & 112 & \multirow[b]{2}{*}{ Average depth } & 10 \\
\hline & Sand to Cobbles & & Sand to Cobbles \\
\hline Predominant bed $m$ & & Bank material & inuous with semi- \\
\hline
\end{tabular}

alluvial channel boundaries and wide point bars.

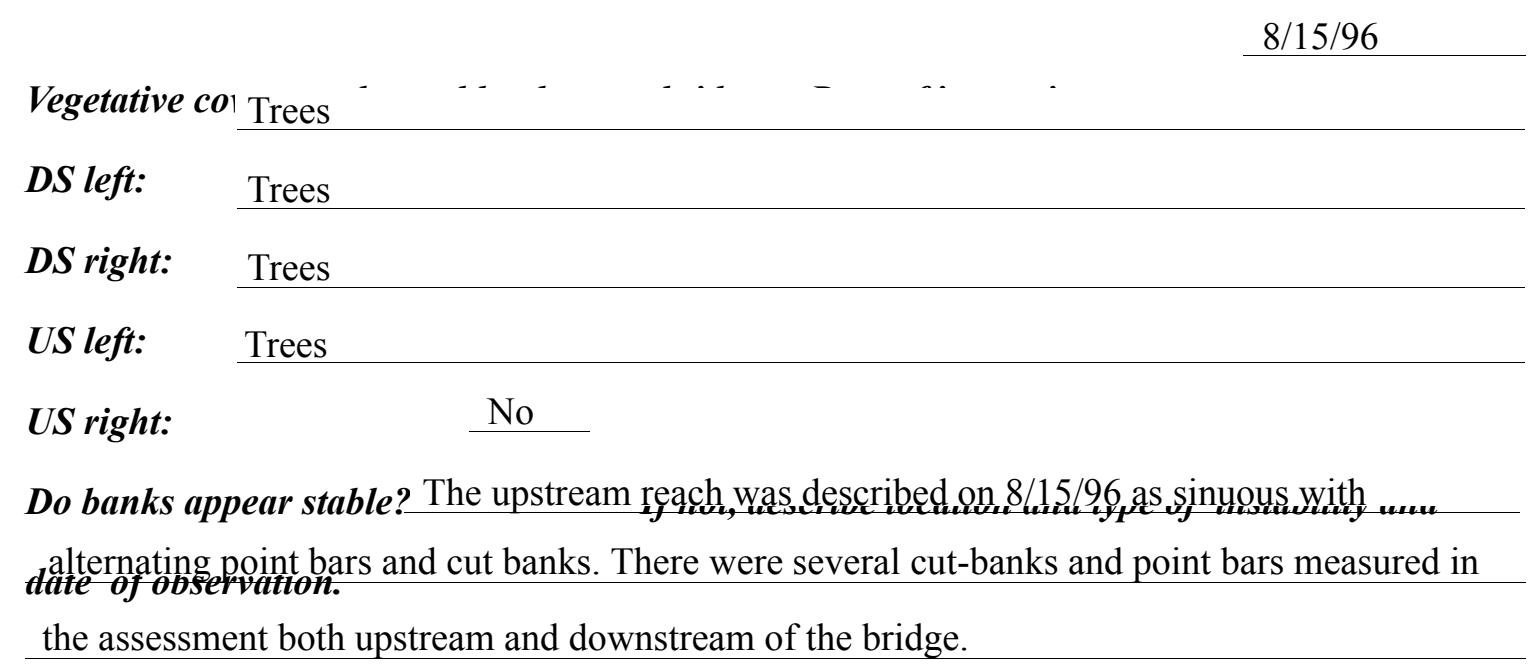




\section{Hydrology}

Drainage area $\stackrel{57.4}{\mathrm{mi}^{2}}$

Percentage of drainage area in physiographic provinces: (approximate)

Physiographic province/section New England / New England Upland
Percent of drainage area 100

Is drainage area considered rural or urban? — Rural _ Describe any significant urbanization:

Yes

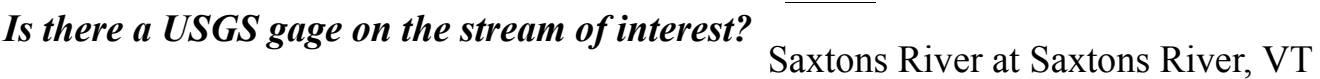
USGS gage description 01154000 (Discontinued, 1982)

USGS gage number 72.2

Gage drainage area $\quad \mathrm{mi}^{2}$ No

Is there a lake/p -

\section{Calculated Discharges $\quad \underline{13,800}$ $\mathrm{ft}^{3} / \mathrm{s}$ \\ Q500 $\quad \mathrm{ft}^{3} / \mathrm{s}$}

The 100- and 500-year discharges are based on a

drainage area relationship [(57.4/59.1) exp 0.75] with the flood frequency curve values for the Saxtons River above the confluence of Leach Creek from the Flood Insurance Study for the Town of Rockingham and Village of Bellows Falls (Federal Emergency Management Agency, 1979). The computed discharges were within a range defined by flood frequency curves computed by use of several empirical methods (Benson, 1962; FHWA, 1983; Johnson and Tasker, 1974; Potter, 1957a\&b; Talbot, 1887) and values available from the VTAOT database (VTAOT, written communication, May 1995). 


\section{Description of the Water-Surface Profile Model (WSPRO) Analysis}

Datum for WSPRO analysis (USGS survey, sea level, VTAOT plans)

USGS survey

Datum tie between USGS survey and VTAOT plans

Add 7.0 feet to the USGS

arbitrary survey datum to obtain the VTAOT plans' datum.

Description of reference marks used to determine USGS datum. $\quad$ RM1 is the center point

of a chiseled "X" on top of the concrete curb at the downstream left corner of the bridge deck

(elev. 499.73 feet, arbitrary survey datum). RM2 is a metallic tablet engraved with "VT highway

dept. bench mark" set in the top of the concrete curb at the downstream right corner of the bridge

deck (elev. 497.08 feet, arbitrary survey datum).

\section{Cross-Sections Used in WSPRO Analysis}

\begin{tabular}{cccl}
\hline${ }^{1}$ Cross-section & $\begin{array}{c}\text { Section } \\
\text { Reference } \\
\text { Distance } \\
(\text { SRD) in feet }\end{array}$ & $\begin{array}{c}{ }^{2} \text { Cross-section } \\
\text { development }\end{array}$ & \multicolumn{1}{c}{ Comments } \\
\hline EXITX & -84 & 1 & $\begin{array}{l}\text { Exit section } \\
\text { Downstream Full-valley } \\
\text { section (Templated from } \\
\text { EXITX) }\end{array}$ \\
BRIDG & 0 & 2 & $\begin{array}{l}\text { Bridge section } \\
\text { RDWAY }\end{array}$ \\
APPRO & 10 & 1 & $\begin{array}{l}\text { Road Grade section } \\
\text { Modelled Approach } \\
\text { section (Templated from } \\
\text { APTEM) }\end{array}$ \\
APTEM & 97 & 2 & $\begin{array}{l}\text { Approach section as } \\
\text { surveyed (Used as a } \\
\text { template) }\end{array}$ \\
\hline
\end{tabular}

${ }^{1}$ For location of cross-sections see plan-view sketch included with Level I field form, Appendix E. For more detail on how cross-sections were developed see WSPRO input file. 


\section{Data and Assumptions Used in WSPRO Model}

Hydraulic analyses of the reach were done by use of the Federal Highway Administration's WSPRO step-backwater computer program (Shearman and others, 1986, and Shearman, 1990). The analyses reported herein reflect conditions existing at the site at the time of the study. Furthermore, in the development of the model it was necessary to assume no accumulation of debris or ice at the site. Results of the hydraulic model are presented in the Bridge Hydraulic Summary, Appendix B, and figure 7.

Channel roughness factors (Manning's " $n$ ") used in the hydraulic model were estimated using field inspections at each cross section following the general guidelines described by Arcement and Schneider (1989). Final adjustments to the values were made during the modelling of the reach. Channel " $n$ " values for the reach ranged from 0.040 to 0.050 , and overbank " $\mathrm{n}$ " values ranged from 0.035 to 0.070 .

Normal depth at the exit section (EXITX) was assumed as the starting water surface. This depth was computed by use of the slope-conveyance method outlined in the user's manual for WSPRO (Shearman, 1990). The slope used was $0.0085 \mathrm{ft} / \mathrm{ft}$, which was estimated from the 100-year water surface slope downstream of this site documented in the Flood Insurance Study for the Town of Rockingham and Village of Bellows Falls (Federal Emergency Management Agency, 1979).

The surveyed approach section (APTEM) was moved along the approach channel slope $(0.0336 \mathrm{ft} / \mathrm{ft})$ to establish the modelled approach section (APPRO), one bridge length upstream of the upstream face as recommended by Shearman and others (1986). This location also provides a consistent method for determining scour variables.

For the 500-year and incipient overtopping discharges modeled, WSPRO assumes critical depth at the bridge section. Supercritical models were developed for these discharges. After analyzing both the supercritical and subcritical profiles for each discharge, it was determined that the water surface profile does pass through critical depth within the bridge opening. Thus, the assumptions of critical depth at the bridge are satisfactory solutions. 


\section{Bridge Hydraulics Summary}

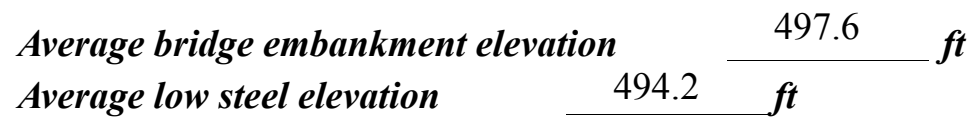

\begin{tabular}{|c|c|c|c|c|}
\hline \multirow{2}{*}{\multicolumn{3}{|c|}{$\begin{array}{l}\text { 100-year discharge } \\
\text { Water-surface elevation in bridge opening }\end{array}$}} & \multirow{2}{*}{\multicolumn{2}{|c|}{$486.5 \mathrm{ft}$}} \\
\hline & & & & \\
\hline Road overtopping? & No & \multicolumn{2}{|c|}{ Discharge over road } & -- \\
\hline \multicolumn{2}{|c|}{ Area of flow in bridge opening } & \multicolumn{2}{|c|}{$566 \quad f t^{2}$} & \\
\hline Average velocity in $b$ & e openin & 16.1 & $f t / s$ & \\
\hline Maximum WSPRO & velocity & at bridoe & 20.0 & $\mathrm{t} / \mathrm{s}$ \\
\hline
\end{tabular}

Water-surface elevation at Approach section with bridge 490.7

Water-surface elevation at Approach section without bridge $\quad \overline{489.2}$

Amount of backwater caused by bridge $\quad 1.5$ it

500-year discharge $\quad 13,800 \quad \mathrm{ft}^{3} / \mathrm{s}$

Water-surface elevation in bridge opening $\quad 488.9$ ft

Road overtopping? ___ Yes Discharge over road __ $413 \quad \mathrm{ft}^{3} / \mathrm{s}$

\begin{tabular}{lccc} 
Area of flow in bridge opening & $733 \quad \boldsymbol{f t}^{2}$ & \\
\cline { 2 - 3 } Average velocity in bridge opening & $18.3 \quad \mathrm{ft} / \mathrm{s}$
\end{tabular}

Maximum WSPRO tube velocity at bridge 22.5 _s

Water-surface elevation at Approach section with bridge 494.4

Water-surface elevation at Approach section without bridge $\quad 491.4$

Amount of backwater caused by bridge $\quad 3.0$.

Incipient overtopping discharge $\quad 12,130 \quad \mathrm{ft}^{3} / \mathrm{s}$

Water-surface elevation in bridge opening 488.2 it

Area of flow in bridge opening $\quad 686 \quad \mathrm{ft}^{2}$

Average velocity in bridge opening $17.7 \quad \mathrm{ft} / \mathrm{s}$

Maximum WSPRO tube velocity at bridge $\quad 21.9 \quad \mathrm{ft} / \mathrm{s}$

Water-surface elevation at Approach section with bridge 493.6.

Water-surface elevation at Approach section without bridge $\quad 490.8$

Amount of backwater caused by bridge $\quad 2.8$ it 


\section{Scour Analysis Summary}

\section{Special Conditions or Assumptions Made in Scour Analysis}

Scour depths were computed using the general guidelines described in Hydraulic Engineering Circular 18 (Richardson and others, 1995). Scour depths were calculated assuming an infinite depth of erosive material and a homogeneous particle-size distribution. The results of the scour analysis are presented in tables 1 and 2 and a graph of the scour depths is presented in figure 8 .

Contraction scour was computed by use of the clear-water contraction scour equation (Richardson and others, 1995, p. 32, equation 20). For contraction scour computations, the average depth in the contracted section (AREA/TOPWIDTH) is subtracted from the depth of flow computed by the scour equation (Y2) to determine the actual amount of scour. The depth to armoring computed for each modeled discharge indicates streambed armoring will not limit contraction scour.

Abutment scour was computed by use of the Froehlich equation (Richardson and others, 1995, p. 48, equation 28). Variables for the Froehlich equation include the Froude number of the flow approaching the embankments, the length of the embankment blocking flow, and the depth of flow approaching the embankment less any roadway overtopping. 


\section{Scour Results}

$$
\text { 100-yr discharge 500-yr discharge }
$$

Contraction scour:

Main channel

Live-bed scour

Clear-water scour

Depth to armoring

Left overbank

Right overbank

Local scour:

Abutment scour

Left abutment

Right abutment

Pier scour

Pier 1

Pier 2

Pier 3
(Scour depths in feet) discharge

Incipient overtopping

(Scour depths in feet)

(1)

\begin{tabular}{crrr}
-- & -- & -- \\
$43.4^{-}$ & & 3.8 & 3.3 \\
$--^{-}$ & $73.6^{-}$ & $63.6^{-}$ \\
-- & $--^{-}$ & -- \\
& --- & -- \\
\hline
\end{tabular}

\section{4}

$26.2-$

23.2

31.6-

22.1

$32.4-$

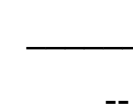

\section{Riprap Sizing}

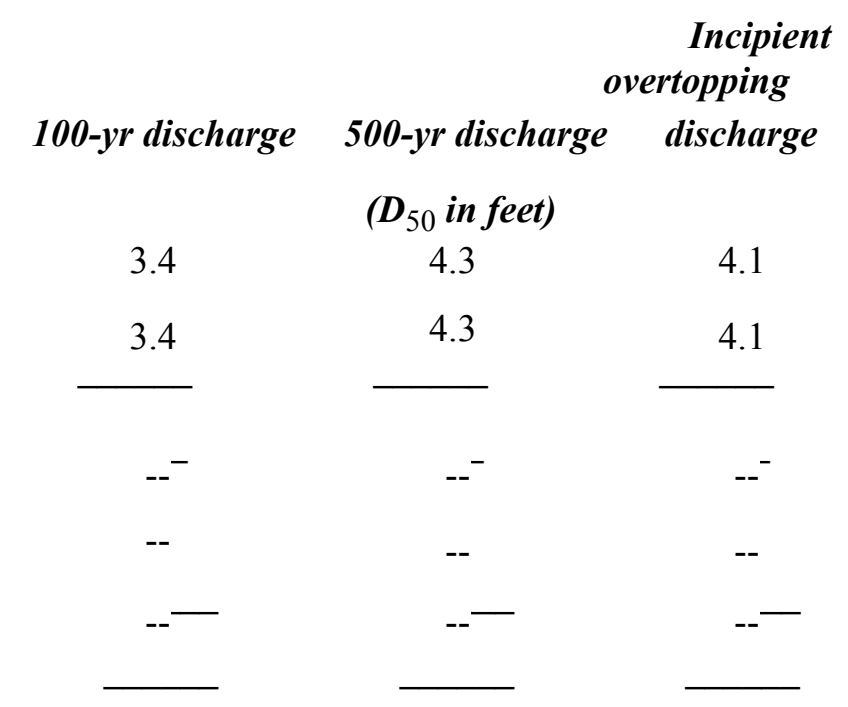




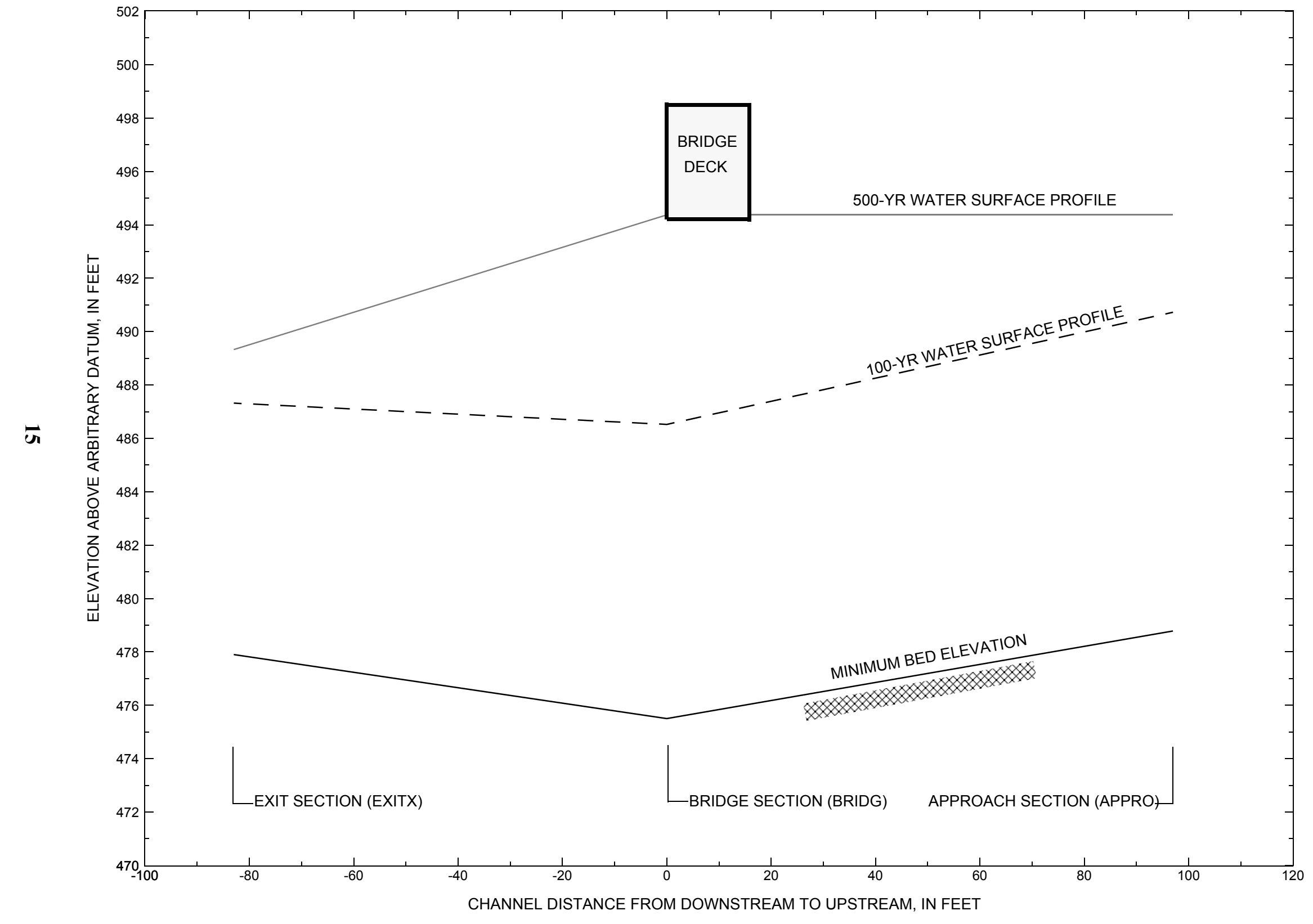

Figure 7. Water-surface profiles for the 100- and 500-yr discharges at structure ROCKTH00390041 on Town Highway 39, crossing Saxtons River, Rockingham, Vermont. 


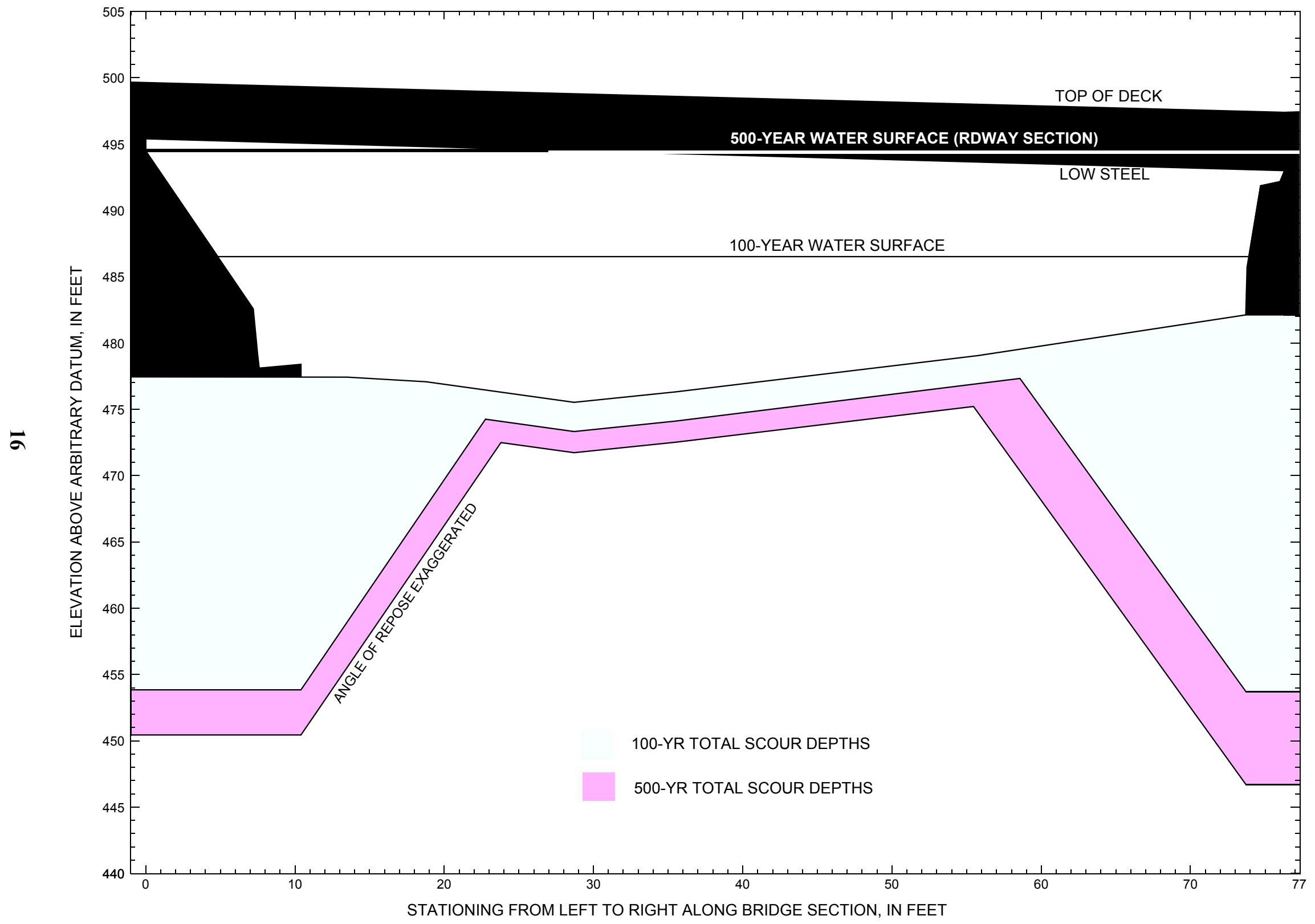

Figure 8. Scour elevations for the 100-yr and 500-yr discharges at structure ROCKTH00390041 on Town Highway 39, crossing Saxtons River, Rockingham, Vermont. 
Table 1. Remaining footing/pile depth at abutments for the 100-year discharge at structure ROCKTH00390041 on Town Highway 39, crossing Saxtons River, Rockingham, Vermont.

[VTAOT, Vermont Agency of Transportation; --,no data]

\begin{tabular}{|c|c|c|c|c|c|c|c|c|c|c|c|}
\hline Description & Station $^{1}$ & $\begin{array}{l}\text { VTAOT } \\
\text { bridge seat } \\
\text { elevation } \\
\text { (feet) }\end{array}$ & $\begin{array}{c}\text { Surveyed } \\
\text { minimum } \\
\text { low-chord } \\
\text { elevation } \\
\text { (feet) }\end{array}$ & $\begin{array}{l}\text { Bottom of } \\
\text { footing } \\
\text { elevation } \\
\text { (feet) }\end{array}$ & $\begin{array}{c}\text { Channel } \\
\text { elevation at } \\
\text { abutment/ } \\
\text { pier }^{2} \\
\text { (feet) }\end{array}$ & $\begin{array}{l}\text { Contraction } \\
\text { scour depth } \\
\text { (feet) }\end{array}$ & $\begin{array}{l}\text { Abutment } \\
\text { scour } \\
\text { depth } \\
\text { (feet) }\end{array}$ & $\begin{array}{l}\text { Pier } \\
\text { scour } \\
\text { depth } \\
\text { (feet) }\end{array}$ & $\begin{array}{l}\text { Depth of } \\
\text { total scour } \\
\text { (feet) }\end{array}$ & $\begin{array}{c}\text { Elevation of } \\
\text { scour }^{2} \\
\text { (feet) }\end{array}$ & $\begin{array}{c}\text { Remaining } \\
\text { footing/pile } \\
\text { depth } \\
\text { (feet) }\end{array}$ \\
\hline \multicolumn{12}{|c|}{100 -yr. discharge is 9,100 cubic-feet per second } \\
\hline Left abutment & 0.0 & 501.8 & 495.4 & 478 & 477.4 & 2.2 & 21.4 & -- & 23.6 & 453.8 & -24 \\
\hline Right abutment & 76.3 & 499.4 & 493.0 & 483 & 482.1 & 2.2 & 26.2 & -- & 28.4 & 453.7 & -29 \\
\hline
\end{tabular}

1.Measured along the face of the most constricting side of the bridge.

2.Arbitrary datum for this study.

Table 2. Remaining footing/pile depth at abutments for the 500-year discharge at structure ROCKTH00390041 on Town Highway 39, crossing Saxtons River, Rockingham, Vermont.

[VTAOT, Vermont Agency of Transportation; --, no data]

\begin{tabular}{|c|c|c|c|c|c|c|c|c|c|c|c|}
\hline Description & Station $^{1}$ & $\begin{array}{c}\text { VTAOT } \\
\text { bridge seat } \\
\text { elevation } \\
\text { (feet) }\end{array}$ & $\begin{array}{l}\text { Surveyed } \\
\text { minimum } \\
\text { low-chord } \\
\text { elevation }{ }^{2} \\
\text { (feet) }\end{array}$ & $\begin{array}{c}\text { Bottom of } \\
\text { footing } \\
\text { elevation } \\
\text { (feet) }\end{array}$ & $\begin{array}{c}\text { Channel } \\
\text { elevation at } \\
\text { abutment/ } \\
\text { pier }^{2} \\
\text { (feet) }\end{array}$ & $\begin{array}{l}\text { Contraction } \\
\text { scour depth } \\
\text { (feet) }\end{array}$ & $\begin{array}{l}\text { Abutment } \\
\text { scour } \\
\text { depth } \\
\text { (feet) }\end{array}$ & $\begin{array}{l}\text { Pier } \\
\text { scour } \\
\text { depth } \\
\text { (feet) }\end{array}$ & $\begin{array}{l}\text { Depth of } \\
\text { total scour } \\
\text { (feet) }\end{array}$ & $\begin{array}{c}\text { Elevation of } \\
\text { scour }^{2} \\
\text { (feet) }\end{array}$ & $\begin{array}{c}\text { Remaining } \\
\text { footing/pile } \\
\text { depth } \\
\text { (feet) }\end{array}$ \\
\hline \multicolumn{12}{|c|}{500 -yr. discharge is 13,800 cubic-feet per second } \\
\hline Left abutment & 0.0 & 501.8 & 495.4 & 478 & 477.4 & 3.8 & 23.2 & -- & 27.0 & 450.4 & -28 \\
\hline Right abutment & 76.3 & 499.4 & 493.0 & 483 & 482.1 & 3.8 & 31.6 & -- & 35.4 & 446.7 & -36 \\
\hline
\end{tabular}

1.Measured along the face of the most constricting side of the bridge.

2.Arbitrary datum for this study. 


\section{SELECTED REFERENCES}

Arcement, G.J., Jr., and Schneider, V.R., 1989, Guide for selecting Manning's roughness coefficients for natural channels and flood plains: U.S. Geological Survey Water-Supply Paper 2339, 38 p.

Barnes, H.H., Jr., 1967, Roughness characteristics of natural channels: U.S. Geological Survey Water-Supply Paper 1849,213 p.

Benson, M. A., 1962, Factors Influencing the Occurrence of Floods in a Humid Region of Diverse Terrain: U.S. Geological Survey WaterSupply Paper 1580-B, 64 p.

Brown, S.A. and Clyde, E.S., 1989, Design of riprap revetment: Federal Highway Administration Hydraulic Engineering Circular No. 11, Publication FHWA-IP-89-016, 156 p.

Federal Highway Administration, 1983, Runoff estimates for small watersheds and development of sound design: Federal Highway Administration Report FHWA-RD-77-158

Federal Emergency Management Agency, 1979, Flood Insurance Study, Town of Rockingham and Village of Bellows Falls, Windham County, Vermont: Washington, D.C., November, 1979.

Froehlich, D.C., 1989, Local scour at bridge abutments in Ports, M.A., ed., Hydraulic Engineering--Proceedings of the 1989 National Conference on Hydraulic Engineering: New York, American Society of Civil Engineers, p. 13-18.

Hayes, D.C.,1993, Site selection and collection of bridge-scour data in Delaware, Maryland, and Virginia: U.S. Geological Survey WaterResources Investigation Report 93-4017, 23 p.

Interagency Advisory Committee on Water Data, 1982, Guidelines for determining flood flow frequency: U.S. Geological Survey, Bulletin 17B of the Hydrology Subcommittee, 190 p.

Johnson, C.G. and Tasker, G.D.,1974, Progress report on flood magnitude and frequency of Vermont streams: U.S. Geological Survey OpenFile Report 74-130, 37 p.

Lagasse, P.F., Schall, J.D., Johnson, F., Richardson, E.V., Chang, F., 1995, Stream Stability at Highway Structures: Federal Highway Administration Hydraulic Engineering Circular No. 20, Publication FHWA-IP-90-014, 144 p.

Laursen, E.M., 1960, Scour at bridge crossings: Journal of the Hydraulics Division, American Society of Civil Engineers, v. 86, no. HY2, p. 39-53.

Potter, W. D., 1957a, Peak rates of runoff in the Adirondack, White Mountains, and Maine woods area, Bureau of Public Roads

Potter, W. D., 1957b, Peak rates of runoff in the New England Hill and Lowland area, Bureau of Public Roads

Richardson, E.V. and Davis, S.R., 1995, Evaluating scour at bridges: Federal Highway Administration Hydraulic Engineering Circular No. 18, Publication FHWA-IP-90-017, 204 p.

Richardson, E.V., Simons, D.B., and Julien, P.Y., 1990, Highways in the river environment: Federal Highway Administration Publication FHWA-HI-90-016.

Ritter, D.F., 1984, Process Geomorphology: W.C. Brown Co., Debuque, Iowa, 603 p.

Shearman, J.O., 1990, User's manual for WSPRO--a computer model for water surface profile computations: Federal Highway Administration Publication FHWA-IP-89-027, 187 p.

Shearman, J.O., Kirby, W.H., Schneider, V.R., and Flippo, H.N., 1986, Bridge waterways analysis model; research report: Federal Highway Administration Publication FHWA-RD-86-108, 112 p.

Talbot, A.N., 1887, The determination of water-way for bridges and culverts.

U.S. Department of Transportation, 1993, Stream stability and scour at highway bridges, Participant Workbook: Federal Highway Administration Publication FHWA HI-91-011.

U.S. Geological Survey, 1984, Saxtons River, Vermont 7.5 by 15 Minute Series quadrangle map: U.S. Geological Survey Topographic Maps, Aerial photographs, 1977, Contour interval, 6 meters; Scale 1:25,000. 


\section{APPENDIX A: \\ WSPRO INPUT FILE}




\section{WSPRO INPUT FILE}

*

SK

$\mathrm{XS}$

GR

GR

GR

GR

GR

GR

$\mathrm{N}$

SA

XS

GR

GR

GR

GR

GR

*

$\mathrm{CD}$

$\mathrm{N}$

XR

GR

GR

GR

GR

$\mathrm{XT}$

GR

GR

GR

GR

GR

GR

AS

GT

$\mathrm{N}$

SA

*P 1 BRIDG 486.521486 .52

HP 2 BRIDG 486.52 * * 9100

HP 1 APPRO 490.721490 .72

HP 2 APPRO 490.72 * * 9100

*

HP 1 BRIDG 488.911488 .91

HP 2 BRIDG 488.91 * *13387

HP 2 RDWAY 494.37 * * 413

HP 1 APPRO 494.371494 .37

HP 2 APPRO 494.37 * * 13800

*

HP 1 BRIDG 488.241488 .24

HP 2 BRIDG 488.24 * * 12450

HP 1 APPRO $493.57 \quad 1493.57$

HP 2 APPRO 493.57 * * 12130

EX

$\mathrm{ER}$
$-36.8,497.03$

$0.0,479.17$

$62.7,479.22$

$95.4,486.88$

$53.7,478.10$

$84.8,485.09$

$323.3,496.07$

$338.5,494.69$

0.060

84.8

0.0000

XSSKEW

0.0

$0.0,494.46$

$10.4,478.39$

$28.7,475.53$

$73.7,482.12$

$76.2,492.68$

$7.2,482.58$

$10.4,477.44$

$35.5,476.32$

$73.8,485.72$

$76.3 ， 493.00$

$-24.8,496.70$

$7.9,477.90$

$67.0,480.57$

$205.1,488.84$

$358.8,495.27$

$$
\begin{array}{r}
7.5,479.12 \\
13.5,477.42 \\
42.5,477.32 \\
74.7,491.85 \\
0.0,495.40
\end{array}
$$

EMB

$$
\begin{array}{r}
-12.3,499.39 \\
83.7,497.01
\end{array}
$$

$339.8,497.32$

$73.2,497.40$
$177.3,493.14$

$-30.9, \quad 509.37$

$4.0,479.05$

$42.5,479.49$

$101.8,485.68$

$184.0,494.25$

$453.1,502.03$

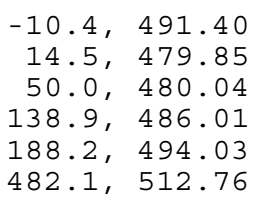

$-11.2,499.82$

$83.9,495.82$

$402.8,502.03$

$-2.9,480.61$

$25.9,479.67$

$59.3,481.17$

$157.2,488.45$

$227.8,493.14$ 


\section{APPENDIX B: \\ WSPRO OUTPUT FILE}


WSPRO OUTPUT FILE

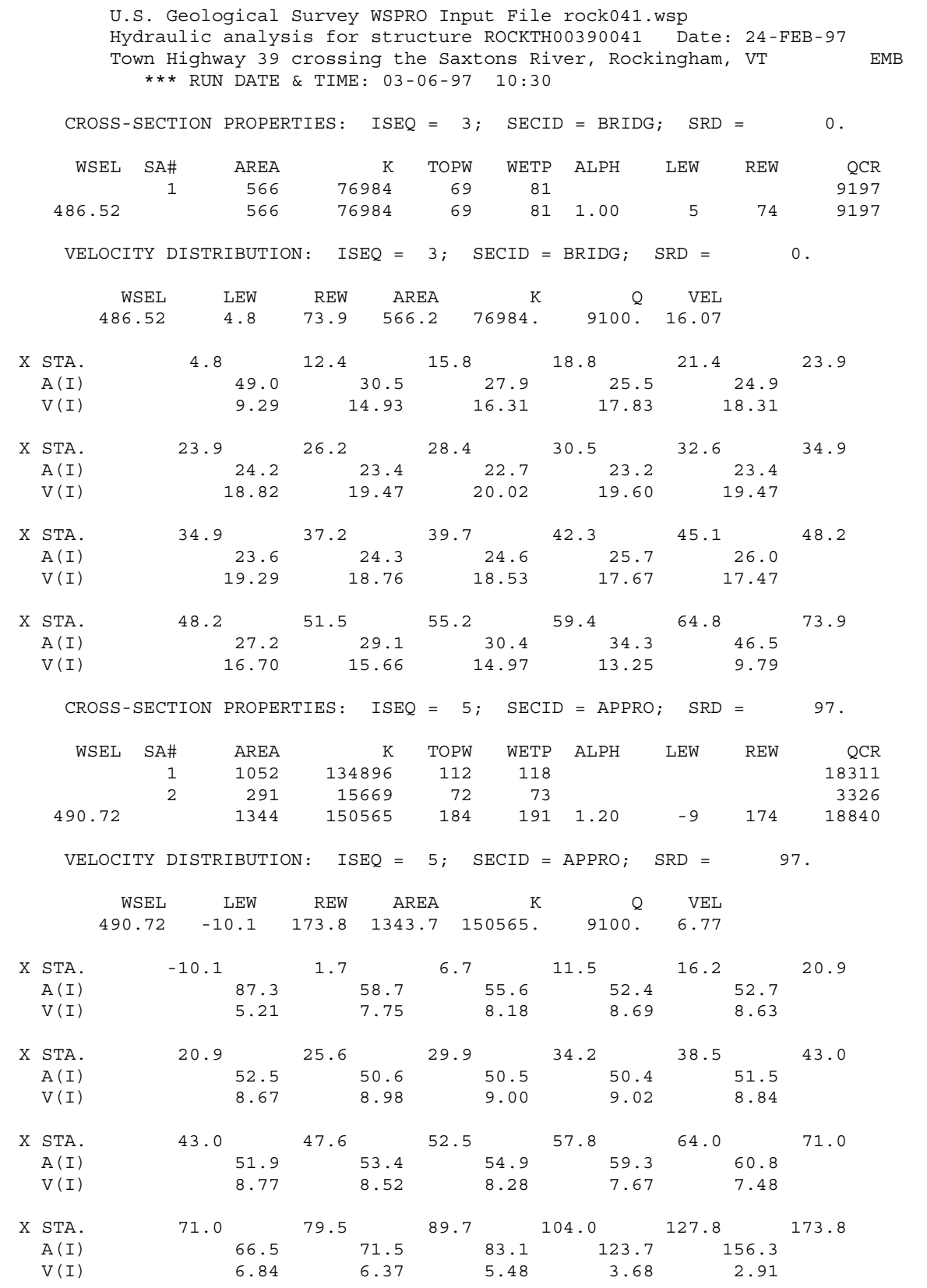


WSPRO OUTPUT FILE (continued)

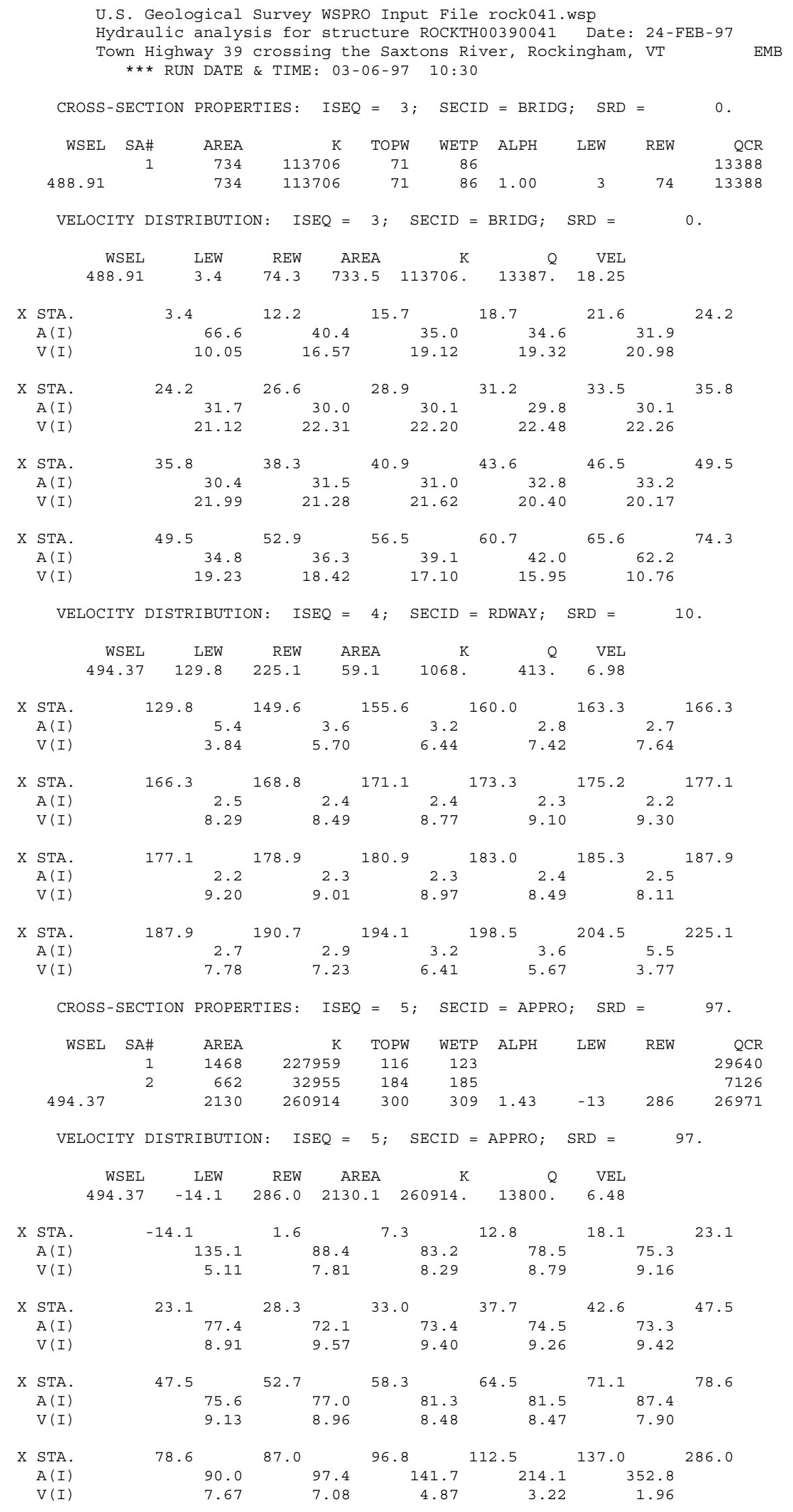


WSPRO OUTPUT FILE (continued)

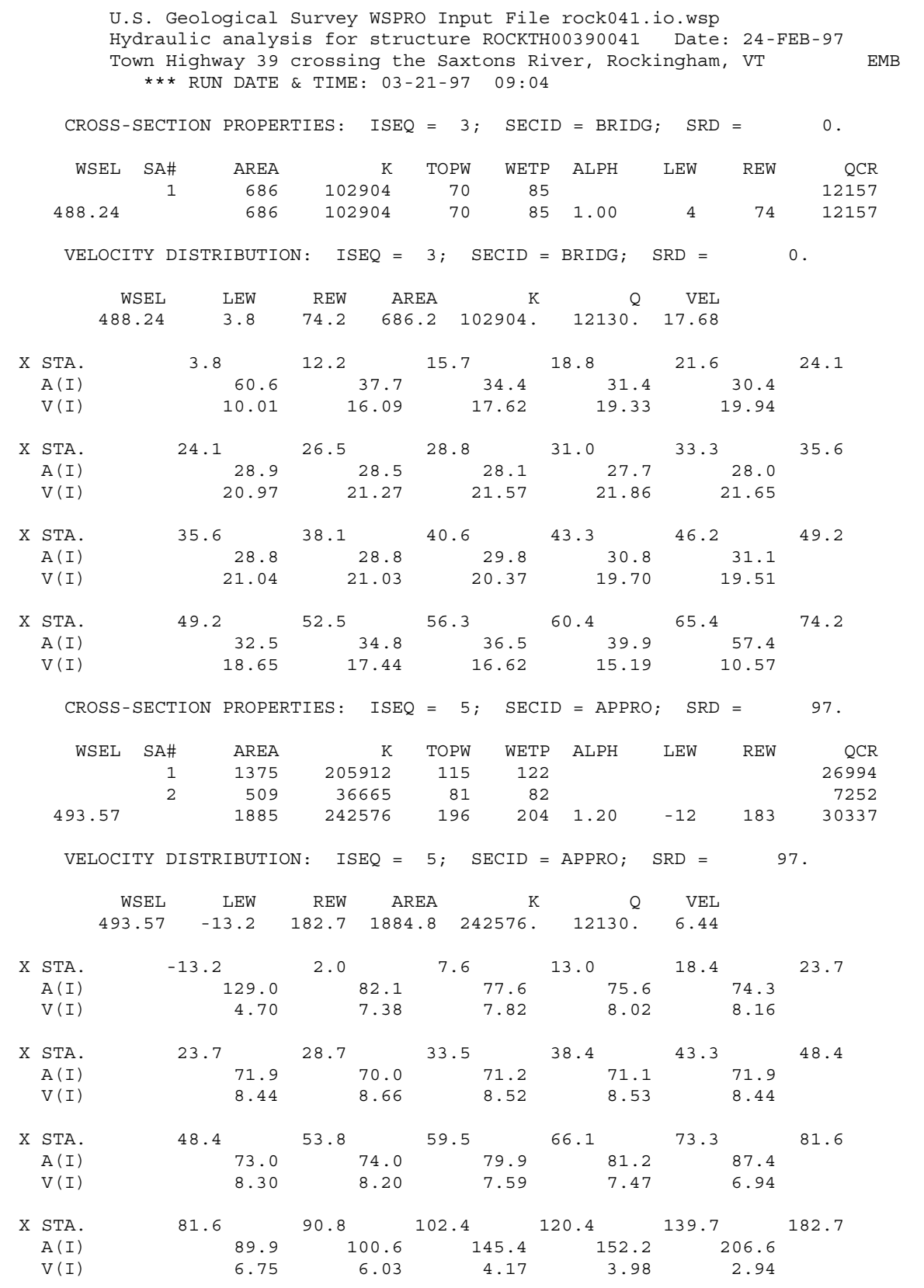


WSPRO OUTPUT FILE (continued)

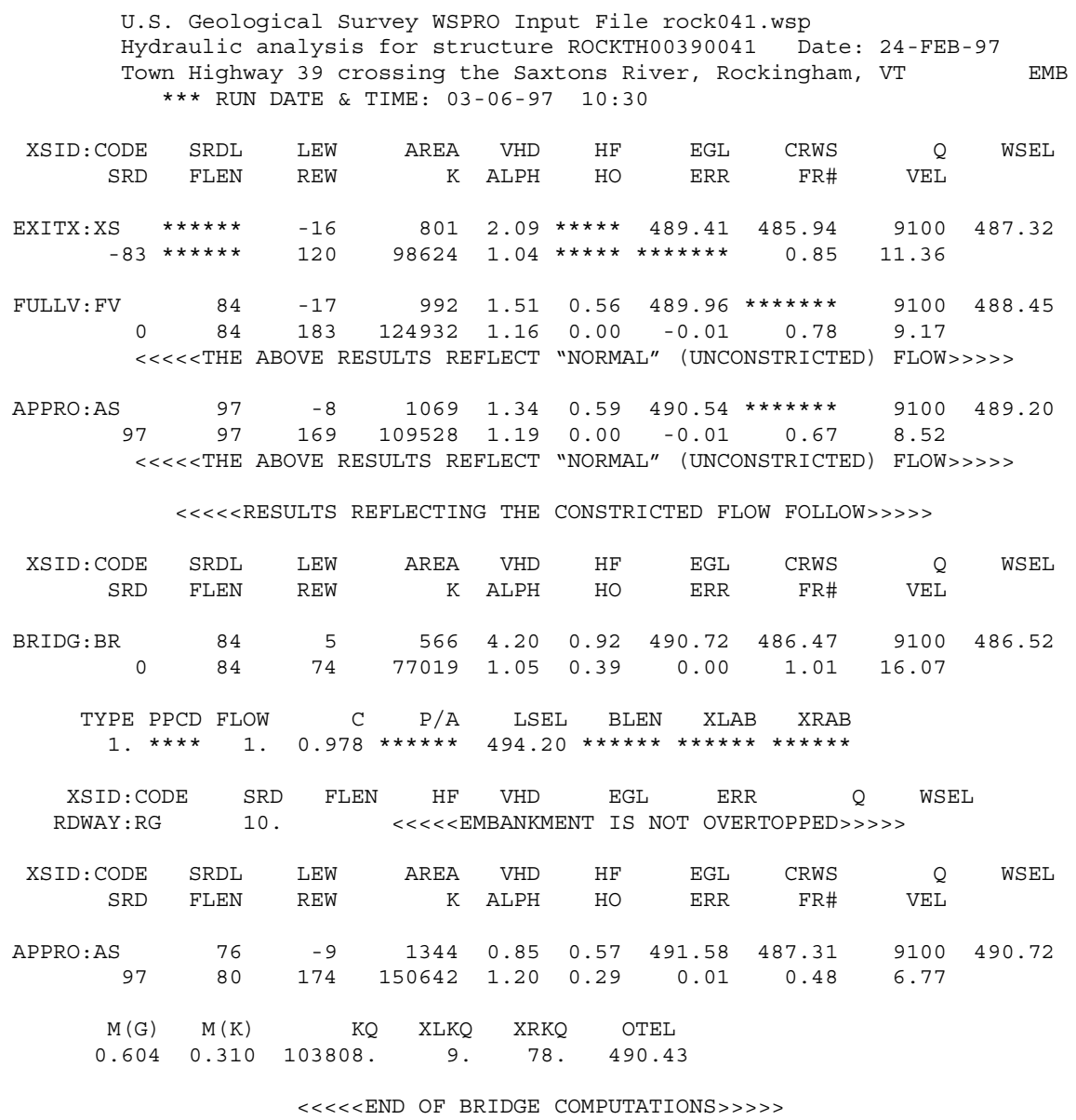

FIRST USER DEFINED TABLE.

\begin{tabular}{|c|c|c|c|c|c|c|c|c|}
\hline XSID : CODE & SRD & LEW & REW & Q & $\mathrm{K}$ & AREA & VEL & WSEL \\
\hline $\operatorname{EXITX}: \mathrm{XS}$ & -84 & -17 & 120. & 9100. & 98624 . & 801. & 11.36 & 487.32 \\
\hline FULLV : FV & 0 . & -18. & 183. & 9100. & 124932 . & 992. & 9.17 & 488.45 \\
\hline BRIDG : BR & 0 & 5 . & 74 & 9100. & 77019 & 566 & 16.07 & 486.52 \\
\hline RDWAY : RG & \multicolumn{3}{|c|}{$10 . * * * * * * * * * * * * * *$} & \multicolumn{3}{|c|}{ 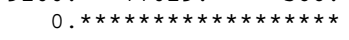 } & \multicolumn{2}{|c|}{$2.00 * * * * * * * *$} \\
\hline APPRO : AS & 97. & -10 & 174 & 9100. & 150642 . & 1344. & 6.77 & 490.72 \\
\hline XSID : CODE & XLKQ & XRKQ & & & & & & \\
\hline APPRO : AS & 9. & 78 & 10380 & & & & & \\
\hline
\end{tabular}

SECOND USER DEFINED TABLE.

\begin{tabular}{|c|c|c|c|c|c|c|c|c|c|}
\hline XSID : CODI & CRWS & FR\# & YMIN & YMAX & $\mathrm{HF}$ & $\mathrm{HO}$ & VHD & EGL & WSEL \\
\hline EXITX:XS & 485.94 & 0.85 & 477.90 & $507.21 *$ & $x$ & $* \star \star \star * *$ & 2.09 & 489.41 & 487.32 \\
\hline FULLV : FV & $\star \star \star \star \star \star \star * \star *$ & .78 & 477.90 & 507.21 & 0.56 & 0.00 & 1.51 & 489.96 & 488.45 \\
\hline BRIDG : BR & 486.47 & 1.01 & 475.53 & 495.40 & 0.92 & 0.39 & 4.20 & 490.72 & 486.52 \\
\hline RDWAY : RG & $\star \star \star \star * * \star * * * \star$ & 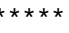 & 493.14 & 512.76 & $\star * * *$ & $* * * *$ & $\star \star \star \star *$ & $\star * \star * \star *$ & 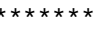 \\
\hline PPRO:AS & 487.31 & 0.48 & 478.78 & 512.49 & 0.57 & 0.29 & 0.85 & 491.58 & 490 \\
\hline
\end{tabular}


WSPRO OUTPUT FILE (continued)

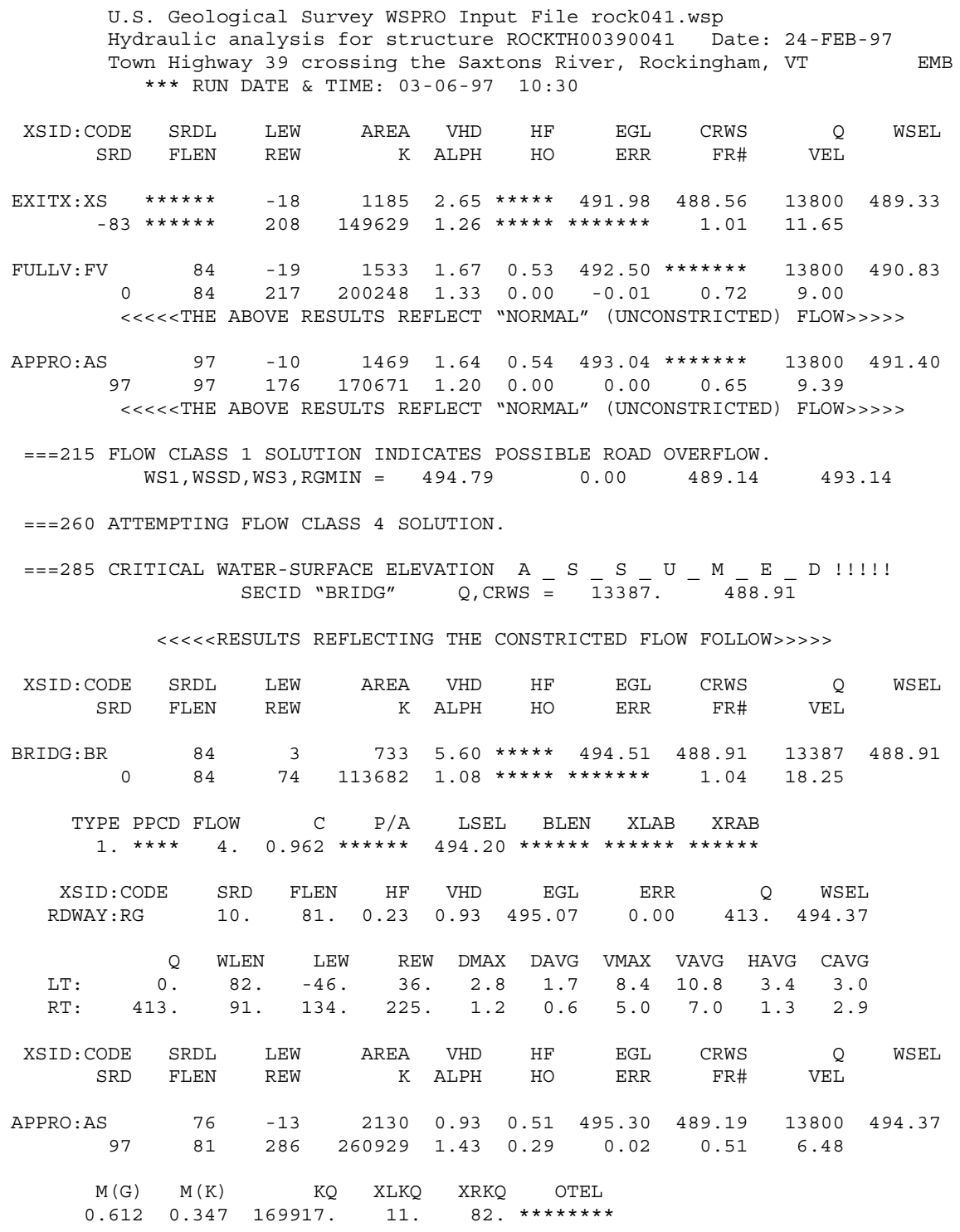

$<<<<$ END OF BRIDGE COMPUTATIONS $>>>>>$

FIRST USER DEFINED TABLE.

\begin{tabular}{|c|c|c|c|c|c|c|c|c|}
\hline XSID : CODE & SRD & LEW & REW & $\mathrm{Q}$ & $\mathrm{K}$ & AREA & VEL & WSEL \\
\hline EXITX:XS & -84. & -19. & 208 . & 13800. & 149629. & 1185. & 11.65 & 489.33 \\
\hline FULLV : FV & 0 . & -20 . & 217 . & 13800 . & 200248 . & 1533. & 9.00 & 490.83 \\
\hline BRIDG : BR & 0 . & 3. & 74 . & 13387. & 113682 . & 733 & 18.25 & 488.91 \\
\hline RDWAY : RG & 10. & 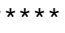 & 0 . & 413 & 0 & $* * * * * *$ & 2.00 & 494.37 \\
\hline APPRO: AS & 97. & -14. & 286. & 13800. & 260929 . & 2130 . & 6.48 & 494.37 \\
\hline XSID : CODE & XLKQ & XRKQ & \multirow{2}{*}{\multicolumn{2}{|c|}{69917}} & & & & \\
\hline APPRO : AS & 11. & 82 . & & & & & & \\
\hline
\end{tabular}

SECOND USER DEFINED TABLE.

$\begin{array}{lrrrrrrrrr}\text { XSID : CODE } & \text { CRWS } & \text { FR\# } & \text { YMIN } & \text { YMAX } & \text { HF } & \text { HO } & \text { VHD } & \text { EGL } & \text { WSEL } \\ \text { EXITX:XS } & 488.56 & 1.01 & 477.90 & 507.21 * * * * * * * * * * & 2.65 & 491.98 & 489.33 \\ \text { FULLV : FV } & * * * * * * * * & 0.72 & 477.90 & 507.21 & 0.53 & 0.00 & 1.67 & 492.50 & 490.83 \\ \text { BRIDG : BR } & 488.91 & 1.04 & 475.53 & 495.40 * * * * * * * * * * * & 5.60 & 494.51 & 488.91 \\ \text { RDWAY : RG } & * * * * * * * * * * * * * * * * & 493.14 & 512.76 & 0.23 * * * * * * & 0.93 & 495.07 & 494.37 \\ \text { APPRO : AS } & 489.19 & 0.51 & 478.78 & 512.49 & 0.51 & 0.29 & 0.93 & 495.30 & 494.37\end{array}$


WSPRO OUTPUT FILE (continued)

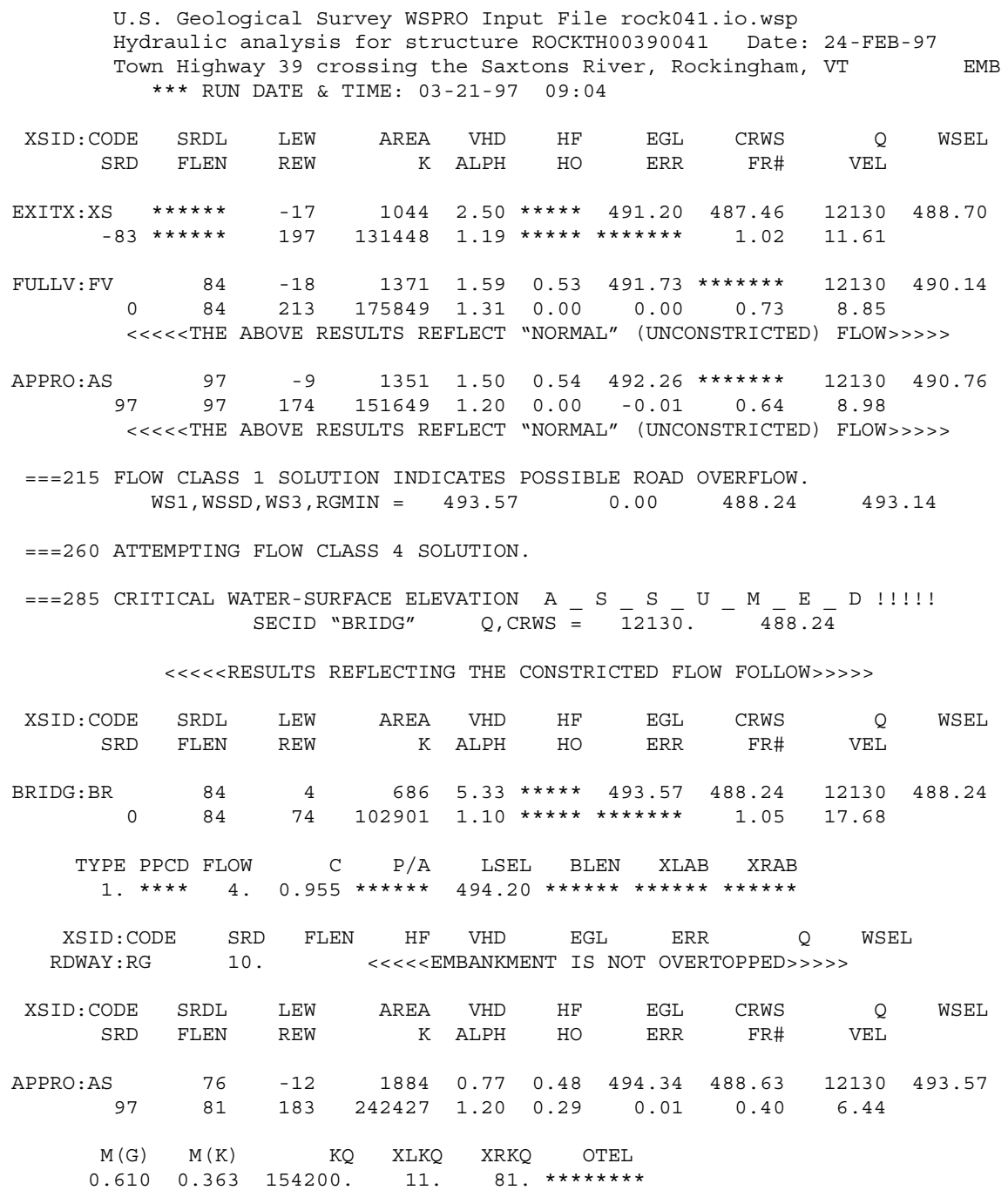

$<<<<<$ END OF BRIDGE COMPUTATIONS $>>>>>$

FIRST USER DEFINED TABLE.

\begin{tabular}{|c|c|c|c|c|c|c|c|c|}
\hline XSID : CODE & SRD & LEW & REW & Q & $\mathrm{K}$ & AREA & VEL & WSEL \\
\hline EXITX:XS & -84. & -18 & 197. & 12130. & 131448 . & 1044 . & 11.61 & 488.70 \\
\hline FULLV: FV & 0 & -19. & 213. & 12130. & 175849 . & 1371. & 8.85 & 490.14 \\
\hline BRIDG : BR & 0. & 4 & 74 . & 12130. & 102901. & 686 & 17.68 & 488.24 \\
\hline RDWAY : RG & 10. & $\star \star \star \star * \star *$ & 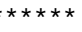 & 0 & 0 & 0 & 2.00 & 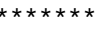 \\
\hline APPRO : AS & 97. & -13 & 183. & 12130. & 242427 . & 1884. & 6.44 & 493.57 \\
\hline XSID : CODE & XLKQ & $\mathrm{XRKQ}$ & \multicolumn{2}{|c|}{$\mathrm{KQ}$} & & & & \\
\hline APPRO : AS & 11. & 81. & \multicolumn{3}{|c|}{154200 . } & & & \\
\hline
\end{tabular}

SECOND USER DEFINED TABLE.

$\begin{array}{lcrrrrrrrr}\text { XSID:CODE } & \text { CRWS } & \text { FR\# } & \text { YMIN } & \text { YMAX } & \text { HF } & \text { HO } & \text { VHD } & \text { EGL } & \text { WSEL } \\ \text { EXITX:XS } & 487.46 & 1.02 & 477.90 & 507.21 * * * * * * * * * * * & 2.50 & 491.20 & 488.70 \\ \text { FULLV:FV } & * * * * * * * & 0.73 & 477.90 & 507.21 & 0.53 & 0.00 & 1.59 & 491.73 & 490.14 \\ \text { BRIDG:BR } & 488.24 & 1.05 & 475.53 & 495.40 * * * * * * * * * * * & 5.33 & 493.57 & 488.24 \\ \text { RDWAY:RG } & * * * * * * * * * * * * * * & 493.14 & 512.76 & 0.20 * * * * * & 0.77 & 494.12 * * * * * * * \\ \text { APPRO:AS } & 488.63 & 0.40 & 478.78 & 512.49 & 0.48 & 0.29 & 0.77 & 494.34 & 493.57 \\ \text { ER } & & & & & & & & & \end{array}$




\section{APPENDIX C:}

\section{BED-MATERIAL PARTICLE-SIZE DISTRIBUTION}




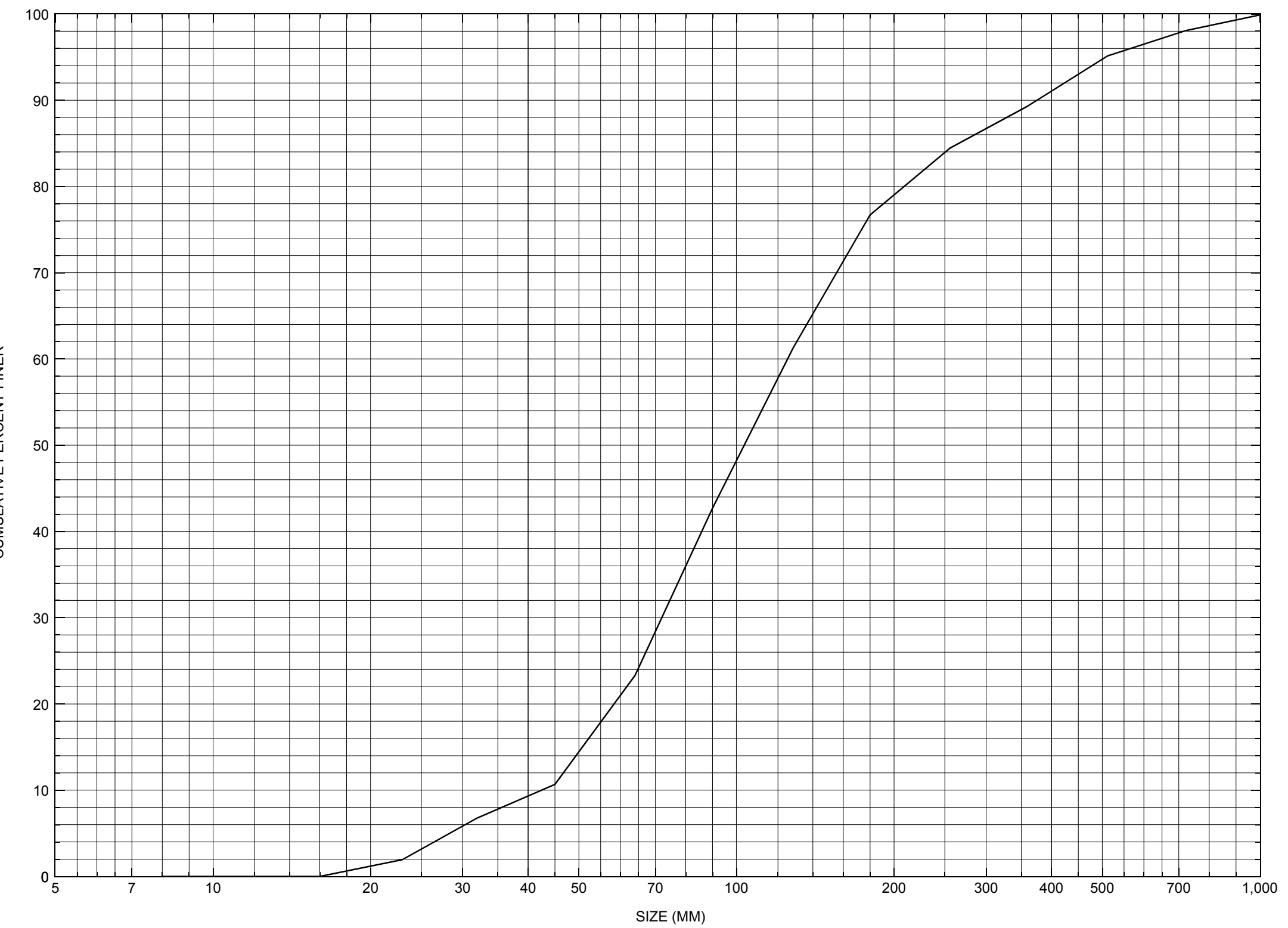

Appendix C. Bed material particle-size distribution for a pebble count in the channel approach of structure ROCKTH00390041, in Rockingham, Vermont. 


\section{APPENDIX D: \\ HISTORICAL DATA FORM}




\section{Structure Number ROCKTH00390041}

\section{General Location Descriptive}

Data collected by (First Initial, Full last name) $\underline{\text { L }}$. MEDALIE

Date $(M M / D D / Y Y) \_\mathbf{0 3} / \underline{31} / \underline{95}$

Highway District Number $(I-2 ; n n) \underline{\mathbf{0 2}}$

Town (FIPS place code; I - 4; nnnnn) $\mathbf{6 0 2 5 0}$

Waterway (I - 6) SAXTONS RIVER

Route Number TH039

Topographic Map Saxtons.River

Latitude (I - 16; nnnn.n) $\mathbf{4 3 0 8 4}$
County (FIPS county code; I - 3; nnn)

Mile marker (I - 11; nnn.nnn) $\mathbf{0 0 0 0 0 0}$

Road Name (I - 7): -

Vicinity $(I$ - 9) $\mathbf{0 . 0 2}$ MI TO JCT W VT121

Hydrologic Unit Code: $\mathbf{0 1 0 8 0 1 0 7}$

Longitude (i - 17; nnnnn.n) $\mathbf{7 2 3 2 4}$

\section{Select Federal Inventory Codes}

FHWA Structure Number (I - 8) 10131400411314

Maintenance responsibility $(I-21 ; n n) \quad \mathbf{0 3}$

Year built (I - 27; YYYY) 1964

Average daily traffic, ADT (I - 29; nnnnnn) 000030

Year of ADT (I - 30; YY) $\mathbf{9 0}$

Opening skew to Roadway $(I-34 ; n n) \quad \mathbf{0 0}$

Operational status $(I-41 ; X)$ A

Structure type (I - 43; nnn) $\mathbf{3 0 2}$

Approach span structure type $(I-44 ; n n n) \quad \mathbf{0 0 0}$

Number of spans (I - 45; nnn) $\mathbf{0 0 1}$

Number of approach spans (I - 46; nnnn) $\mathbf{0 0 0 0}$

Comments:

The structural inspection report indicates that the structure is a single span, steel beam type bridge. Both abutments are concrete. The abutment concrete has very minor staining reported. The waterway makes a slight turn through the structure. The streambed consists of stone and gravel with some random boulders. There is a shallow sand (mud and gravel) point bar with minor vegetation growth in front of the right abutment. There is a bedrock outcrop upstream from the left abutment. There report noted that there was no channel scour, embankment erosion, or structure settlement apparent. The footings are noted as "not in view".
Maximum span length (I - 48; nnnn) $\underline{\mathbf{0 0 8 2}}$

Structure length (I - 49; nnnnnn) $\underline{000085}$

Deck Width (I - 52; nn.n) 158

Channel \& Protection $(I-61 ; n) \underline{7}$

Waterway adequacy $(I-71 ; n) \underline{7}$

Underwater Inspection Frequency $(I-92 B ; X Y Y) \_$N

Year Reconstructed (I - 106) $\mathbf{0 0 0 0}$

Clear span (nnn.n ft) $\mathbf{7 3 . 5}$

Vertical clearance from streambed (nnn.n ft) 16

Waterway of full opening $\left(n n n . n \mathrm{ft}^{2}\right) \mathbf{1 1 7 6}$ 


\section{Bridge Hydrologic Data}

Is there hydrologic data available? $\underline{\mathbf{N}}$ if No, type ctrl-n $h \quad$ VTAOT Drainage area $\left(m i^{2}\right)$ : -

Terrain character:

Stream character \& type: -

Streambed material:

Discharge Data (cfs):

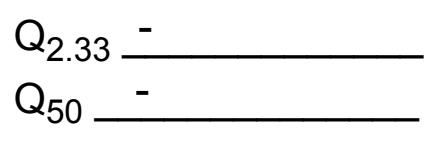

Record flood date $(M M / D D / Y Y):-{ }^{\prime}-$
Estimated Discharge $(c f s):-$

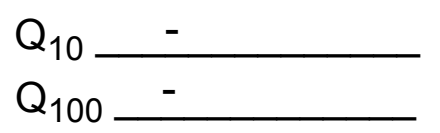

$\mathrm{Q}_{25}$

Water surface elevation $(f t):-$ $(\mathrm{ft} / \mathrm{s}):$

Ice conditions (Heavy, Moderate, Light) : -

Debris (Heavy, Moderate, Light):

The stage increases to maximum highwater elevation (Rapidly, Not rapidly):

The stream response is (Flashy, Not flashy):

Describe any significant site conditions upstream or downstream that may influence the stream's stage: -

Watershed storage area (in percent): __ \%

The watershed storage area is: - _ (1-mainly at the headwaters; 2- uniformly distributed; 3-immediatly upstream oi the site)

Water Surface Elevation Estimates for Existing Structure:

\begin{tabular}{|l|l|l|l|l|l|}
\hline Peak discharge frequency & $Q_{2.33}$ & $Q_{10}$ & $Q_{25}$ & $Q_{50}$ & $Q_{100}$ \\
Water surface elevation (ft)) & - & - & - & - & - \\
Velocity (ft/sec) & - & - & - & - & - \\
\hline
\end{tabular}

Long term stream bed changes: -

Is the roadway overtopped below the $Q_{100}$ ? (Yes, No, Unknown):

Frequency: -

Relief Elevation (ft):

Discharge over roadway at $Q_{100}\left(f t^{3} / \mathrm{sec}\right)$ :

Are there other structures nearby? (Yes, No, Unknown): -

Upstream distance (miles):

Town: If No or Unknown, type ctrl-n os

Highway No. : Structure No. : Year Built:

Clear span (ft): Clear Height $(f t)$ : Full Waterway $\left(f^{2}\right)$ : 
Downstream distance (miles): Town: Year Built:

Highway No. : Structure No. : Structure Type:

Clear span (ft): Clear Height $(f t)$ : Full Waterway $\left(f^{2}\right):$

Comments:

\section{USGS Watershed Data}

Watershed Hydrographic Data

Drainage area $(D A) \underline{\mathbf{5 7 . 3 8}} \mathrm{mi}^{2}$

Watershed storage (ST) 0.6

Bridge site elevation 551

Main channel length

6.80 $\mathrm{ft}$ $\%$

$10 \%$ channel length elevation $\mathbf{5 7 1}$

Lake and pond area

0.23 $\mathrm{mi}^{2}$

Main channel slope
(S) 57.92 $\mathrm{ft} / \mathrm{mi}$

Watershed Precipitation Data

Average site precipitation in

Average headwater precipitation in

Maximum 2yr-24hr precipitation event $(124,2)$ in

Average seasonal snowfall $(S n)$ $\mathrm{ft}$ 


\section{Bridge Plan Data}

Are plans available? $\mathbf{Y}$ If no, type ctrl-n pl Date issued for construction (MM/YYYY): $\mathbf{0 3} / \mathbf{1 9 6 4}$

Project Number TH 3010 \& TF 41/62 Minimum channel bed elevation: 4 885.0

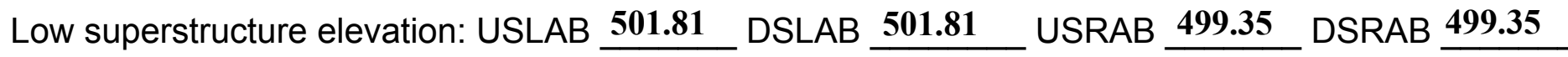

Benchmark location description:

BM \#1: at or near an 18 inch elm tree, elevation 500.0, 94 feet right bankward of the right abutment then

8.8 feet from the centerline of roadway on the downstream side of the roadway.

Reference Point (MSL, Arbitrary, Other): Arbitrary Datum (NAD27, NAD83, Other): Arbitrary

Foundation Type: $\mathbf{3}$ (1-Spreadfooting; 2-Pile; 3- Gravity; 4-Unknown)

If 1 : Footing Thickness ___ Footing bottom elevation: *

If 2: Pile Type:___ (1-Wood; 2-Steel or metal; 3-Concrete) Approximate pile driven length:

If 3: Footing bottom elevation: $\underline{\mathbf{4 8 4 . 5}}$

Is boring information available? $\underline{\mathbf{Y}}$ If no, type ctrl-n bi Number of borings taken: $\mathbf{6}$

Foundation Material Type: 2 (1-regolith, 2-bedrock, 3-unknown)

Briefly describe material at foundation bottom elevation or around piles:

Referencing Right abutment: B1 hit ledge/boulder at 2.0 feet depth (489.5) upstream right bank

B2 hit ledge/boulder at 3.0 feet depth (490.7) downstream right bank

B3 hit ledge/boulder at 11.5 feet depth (493.3) downstream of the right abutment

B4 hit ledge/boulder at 10.0 feet depth (495.5) upstream right abutment

Referencing Left abutment: B5 hit ledge/boulder at 4.0 feet depth (484.2) downstream left bank

B6 hit ledge/boulder at 7.0 feet depth (482.0) upstream of the left bank

Comments:

*Footing bottom elevation left: 484.5 and right: 490.0 . Both abutments sit on boulders or bedrock. 


\section{Cross-sectional Data}

Is cross-sectional data available? $\underline{\mathbf{Y}}$

If no, type ctrl-n xs

Source (FEMA, VTAOT, Other)? VTAOT

Comments: Upstream bridge face cross section at stationing $1+89.5,10.5$ feet from the centerline of the roadway on the bridge deck. The channel baseline runs along the left bank 12 feet from the end of the bridge deck parallel to the abutment wall.

\begin{tabular}{|l|l|l|l|l|l|l|l|l|l|l|l|}
\hline Station & $\mathbf{1 2 . 0}$ & $\mathbf{1 4 . 0}$ & $\mathbf{1 5 . 4}$ & $\mathbf{2 1 . 1}$ & $\mathbf{3 0 . 0}$ & $\mathbf{3 6 . 5}$ & $\mathbf{4 6 . 0}$ & $\mathbf{5 0 . 5}$ & $\mathbf{5 1 . 0}$ & $\mathbf{5 1 . 5}$ & $\mathbf{5 3 . 0}$ \\
\hline Feature & LCL & $\begin{array}{l}\text { top 0f } \\
\text { wall }\end{array}$ & LEW & BLB & & & REW & BRB & $\begin{array}{l}\text { top 0f } \\
\text { wall }\end{array}$ & LCR & \\
\hline $\begin{array}{l}\text { Low cord } \\
\text { elevation }\end{array}$ & $\mathbf{4 9 8 . 5}$ & $\mathbf{4 9 8 . 0}$ & & & & & & & $\mathbf{4 9 3 . 8}$ & $\mathbf{4 9 7 . 3}$ & $\mathbf{4 9 7 . 3}$ \\
\hline $\begin{array}{l}\text { Bed } \\
\text { elevation }\end{array}$ & & & 490.7 & $\mathbf{4 8 9 . 8}$ & $\mathbf{4 8 9 . 8}$ & $\mathbf{4 9 0 . 0}$ & $\mathbf{4 9 0 . 7}$ & $\mathbf{4 9 1 . 6}$ & & & \\
\hline $\begin{array}{l}\text { Low cord to } \\
\text { bed length }\end{array}$ & & & & & & & & & & & \\
\hline Station & & & & & & & & & & & \\
\hline Feature & & & & & & & & & & & \\
\hline $\begin{array}{l}\text { Low cord } \\
\text { elevation }\end{array}$ & & & & & & & & & & & \\
\hline $\begin{array}{l}\text { Bed } \\
\text { elevation }\end{array}$ & & & & & & & & & & & \\
\hline $\begin{array}{l}\text { Low cord to } \\
\text { bed length }\end{array}$ & & & & & & & & & & & \\
\hline
\end{tabular}

Source (FEMA, VTAOT, Other)? VTAOT

Comments: Downstream bridge face cross section at stationing $2+10,10$ feet from the centerline of the roadway on the bridge deck.

\begin{tabular}{|l|l|l|l|l|l|l|l|l|l|l|l|}
\hline Station & $\mathbf{1 2 . 5}$ & $\mathbf{1 5 . 0}$ & $\mathbf{1 6 . 2}$ & $\mathbf{2 4 . 5}$ & $\mathbf{2 9 . 8}$ & $\mathbf{3 8 . 0}$ & $\mathbf{4 5 . 0}$ & $\mathbf{5 0 . 5}$ & $\mathbf{5 1 . 0}$ & $\mathbf{5 1 . 5}$ & \\
\hline Feature & LCL & $\begin{array}{l}\text { top 0f } \\
\text { wall }\end{array}$ & $\begin{array}{l}\text { BLB/ } \\
\text { LEW }\end{array}$ & & & TD & & $\begin{array}{l}\text { BRB/ } \\
\text { REW }\end{array}$ & $\begin{array}{l}\text { top of } \\
\text { wall }\end{array}$ & LCR & \\
\hline $\begin{array}{l}\text { Low cord } \\
\text { elevation }\end{array}$ & 498.5 & 498.5 & & & & & & & 493.8 & & \\
\hline $\begin{array}{l}\text { Bed } \\
\text { elevation }\end{array}$ & & & 490.7 & 490.5 & 489.8 & 489.3 & 489.8 & 490.7 & & 497.3 & \\
\hline $\begin{array}{l}\text { Low cord to } \\
\text { bed length }\end{array}$ & & & & & & & & & & & \\
\hline Station & & & & & & & & & & & \\
\hline Feature & & & & & & & & & & & \\
\hline $\begin{array}{l}\text { Low cord } \\
\text { elevation }\end{array}$ & & & & & & & & & & & \\
\hline $\begin{array}{l}\text { Bed } \\
\text { elevation }\end{array}$ & & & & & & & & & & \\
\hline $\begin{array}{l}\text { Low cord to } \\
\text { bed length }\end{array}$ & & & & & & & & & & & \\
\hline
\end{tabular}




\section{APPENDIX E: \\ LEVEL I DATA FORM}


U. S. Geological Survey

Bridge Field Data Collection and Processing Form

Qa/Qc Check by: $\underline{\mathbf{R B}}$ Date: $10 / 09 / 96$

\section{Structure Number}

ROCKTH00390041

Computerized by: $\underline{\mathbf{R B}}$ Date: $10 / \mathbf{1 0} / 96$

Reviewd by: $\quad$ EB Date: $\underline{3 / 7 / 97}$

\section{A. General Location Descriptive}

1. Data collected by (First Initial, Full last name) J . DEGNAN

2. Highway District Number $\mathbf{0 2}$

County Windham (025)

Waterway (I - 6) Saxtons River

Route Number TH 39

3. Descriptive comments:

This concrete deck bridge is 0.02 miles from the intersection of TH 39 with VT 121 (TH 1, FAS 125).
Mile marker 0000

Town Rockingham (60250)

Road Name -

Hydrologic Unit Code: $\mathbf{0 1 0 8 0 1 0 7}$

Date $(M M / D D / Y Y) \underline{\mathbf{0 8}} / \underline{\mathbf{1 5}} / \underline{1996}$

\section{B. Bridge Deck Observations}
4. Surface cover... LBUS 6
RBUS 4
LBDS 6
RBDS 4
Overall 6

(2b us,ds,lb,rb: 1- Urban; 2- Suburban; 3- Row crops; 4- Pasture; 5- Shrub- and brushland; 6- Forest; 7- Wetland)
5. Ambient water surface...US $\underline{2}$
UB 1
DS 1
(1- pool; 2- riffle)

6. Bridge structure type 1 (1- single span; 2- multiple span; 3- single arch; 4- multiple arch; 5-cylindrical culvert; 6- box culvert; or 7- other)
7. Bridge length 85 (feet)
Span length $\mathbf{8 2}$ (feet)
Bridge width 15.8 (feet)

\section{Road approach to bridge:}
8. LB 2 RB 1
( 0 even, 1- lower, 2- higher)
9. LB_2
RB $\underline{2}$
(1- Paved, 2- Not paved)

10. Embankment slope (run / rise in feet / foot):

US left

US right

\begin{tabular}{|c|c|c|c|}
\hline \multicolumn{2}{|c|}{ Protection } & \multirow{2}{*}{ 13.Erosion } & \multirow{2}{*}{ 14.Severity } \\
\hline 11.Type & 12.Cond. & & \\
\hline 2 & 1 & 3 & 2 \\
\hline 3 & 2 & 1 & 2 \\
\hline 3 & 1 & 1 & 1 \\
\hline 2 & 1 & 3 & 1 \\
\hline
\end{tabular}

Bank protection types: 0- none; 1- < 12 inches;

2- < 36 inches; 3- < 48 inches;

4- $<60$ inches; 5- wall / artificial levee

Bank protection conditions: 1- good; 2- slumped;

3- eroded; 4- failed

Erosion: 0 - none; 1- channel erosion; 2-

road wash; 3- both; 4- other

Erosion Severity: 0 - none; 1- slight; 2- moderate;

\section{Channel approach to bridge (BF):}

15. Angle of approach: $\mathbf{3 5}$

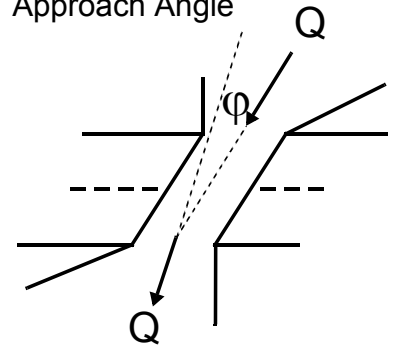

17. Channel impact zone 1:

Where? LB (LB, RB)

Range? 100 feet US

Channel impact zone 2:

Where? $(L B, R B)$

Range? - $\quad$ feet (US, UB, DS) to feet -

Impact Severity: 0- none to very slight; 1-Slight; 2- Moderate; 3- Severe
16. Bridge skew: $\mathbf{3 0}$

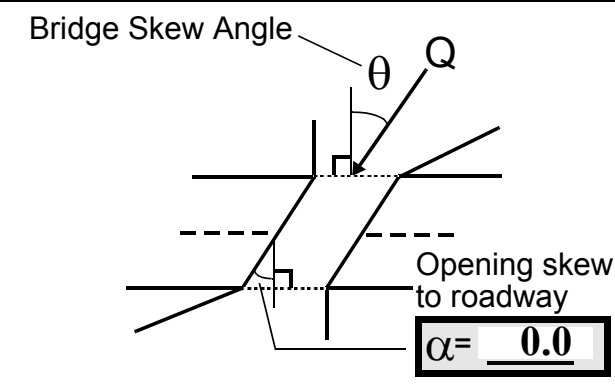

\section{Exist? $\mathbf{Y}(Y$ or $N)$}

Severity 2

(US, UB, DS) to $\underline{\mathbf{3 0}}$ feet $\underline{\mathbf{D S}}$

Exist? $\underline{\mathbf{N}}(\mathrm{Y}$ or $N)$

Severity -

o roadway

\section{3- severe}


18. Bridge Type: $\mathbf{1 b}$

1a- Vertical abutments with wingwalls

$1 \mathrm{~b}$ - Vertical abutments without wingwalls

2- Vertical abutments and wingwalls, sloping embankment Wingwalls perpendicular to abut. face

3- Spill through abutments

4- Sloping embankment, vertical wingwalls and abutments

Wingwall angle less than $90^{\circ}$.

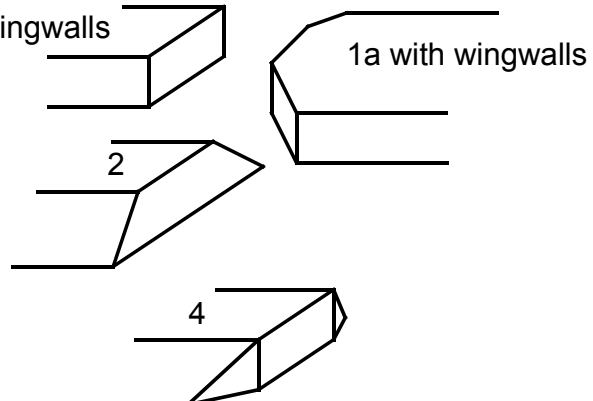

19. Bridge Deck Comments (surface cover variations, measured bridge and span lengths, bridge type variations, approach overflow width, etc.)

4. There are two houses on the DS right bank.

7. Values are from the VT AOT files. Measured bridge dimensions are the same.

10. The right bank road approach protection is rip rap. The left bank road approach protection is dumped stone that also acts as bank protection.

11. The US right bank road approach protection is being slumped by the dry confluence cut bank.

\section{Upstream Channel Assessment}

\begin{tabular}{|c|c|c|c|c|c|c|c|c|c|c|c|}
\hline & \multicolumn{2}{|c|}{ 21. Bank height (BF) 22. Bank anqle (BF) } & 22. $\mathrm{Bc}$ & gle (BF) & \multicolumn{2}{|c|}{ 26. \% Veg. cover (BF) } & \multicolumn{3}{|c|}{ 27. Bank material (BF) } & \multicolumn{2}{|c|}{ 28. Bank erosion (BF) } \\
\hline 20. SRD & LB & $\mathrm{RB}$ & LB & RB & LB & $\mathrm{RB}$ & LB & $\mathrm{RB}$ & & LB & $\mathrm{RB}$ \\
\hline 93.0 & & & & 4.5 & 3 & 3 & 645 & 234 & & 2 & 1 \\
\hline 23. Bank & & 55.0 & 24. $C$ & el width & 5.0 & 25. Tha & veg dep & 2.0 & & ed & 432 \\
\hline
\end{tabular}

30 .Bank protection type:

LB 2

RB 0

31. Bank protection condition: LB 2

$\mathrm{RB}$ -

SRD - Section ref. dist. to US face \% Vegetation (Veg) cover: 1- 0 to 25\%; 2- 26 to $50 \%$; 3- 51 to $75 \%$; $4-76$ to $100 \%$

Bed and bank Material: 0- organics; 1- silt / clay, <1/16mm; 2- sand, 1/16 - 2mm; 3- gravel, 2 - 64mm;

4- cobble, 64 - 256mm; 5- boulder, > 256mm; 6- bedrock; 7-manmade

Bank Erosion: 0- not evident; 1- light fluvial; 2- moderate fluvial; 3- heavy fluvial / mass wasting

Bank protection types: 0- absent; 1- < 12 inches; 2- < 36 inches; 3- < 48 inches; 4- < 60 inches; 5- wall / artificial levee

Bank protection conditions: 1- good; 2- slumped; 3- eroded; 4- failed

32. Comments (bank material variation, minor inflows, protection extent, etc.):

29. There are some boulders in the bed US of the approach cross section and slumped protection on the left bank side just US and under the bridge.

31. The left bank protection protects the road approach also and extends from $40 \mathrm{ft}$. US to $0 \mathrm{ft}$. US.

The bedrock on the left bank extends from $95 \mathrm{ft}$. US to $35 \mathrm{ft}$. US. The channel US consists of alternating point

bars and cut banks. 
36. Point bar extent: $\underline{175}$ feet $\underline{\text { US }}$ (US, UB) to $\underline{\mathbf{5 0}}$ feet DS (US, UB, DS) positioned $\underline{\mathbf{6 6}} \%$ LB to $100 \%$ RB

37. Material: 234

38. Point or side bar comments (Circle Point or Side; Note additional bars, material variation, status, etc.):

The material becomes coarser moving from DS to US. There is some grass and bushes at the US end.

39. Is a cut-bank present? $\mathbf{Y}$ (Y or if $N$ type $c t r-n c b)$

41. Mid-bank distance: $\mathbf{4 5}$

43. Bank damage: 1

42. Cut bank extent: $\mathbf{6 5}$

40. Where? $\underline{\mathbf{L B}}$ (LB or RB)

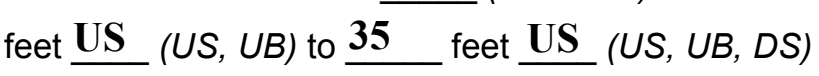

(1- eroded and/or creep; 2- slip failure; 3- block failure)

44. Cut bank comments (eg. additional cut banks, protection condition, etc.):

The cut bank is on top of the bedrock. There is an additional cut bank on the right bank of the confluence that is cutting into the roadway protection.

\section{Is channel scour present? $\mathbf{Y}$ ( $Y$ or if $N$ type ctrl-n cs)}

47. Scour dimensions: Length 90 Width 25 Depth : $\mathbf{3}$

46. Mid-scour distance: $\mathbf{0}$

48. Scour comments (eg. additional scour areas, local scouring process, etc.):

The scour hole extends from $40 \mathrm{ft}$. US to $40 \mathrm{ft}$. DS.

\section{Are there major confluences? $\mathbf{N}$}

51. Confluence 1: Distance Confluence 2: Distance -
52. Enters on -

Enters on -
( $Y$ or if $N$ type ctrl-n $m c)$ ( $L B$ or $R B)$ (LB or $R B)$

54. Confluence comments (eg. confluence name):

NO MAJOR CONFLUENCES There is a dry channel running along the right bank US road approach protection at the bottom of the road embankment.

\section{Under Bridge Channel Assessment}

55. Channel restraint (BF)? LB 2 (1- natural bank; 2- abutment; 3- artificial levee)

\begin{tabular}{|ccccc}
\multicolumn{2}{|c}{ 56. Height (BF) } & \multicolumn{3}{c}{57 Angle (BF) } \\
LB & RB & LB & RB \\
$\mathbf{6 2 . 0}$ & & & $\mathbf{1 . 0}$ & \\
\hline
\end{tabular}

\begin{tabular}{lc} 
61. & Material (BF) \\
LB & RB \\
$\mathbf{2}$ & $\mathbf{7}$ \\
\hline
\end{tabular}

62. Erosion (BF)

LB RB

58. Bank width (BF) -

59. Channel width (Amb) -

60. Thalweg depth (Amb) $\mathbf{9 0 . 0}$

63. Bed Material -

Bed and bank Material: 0- organics; 1- silt / clay, < 1/16mm; 2- sand, 1/16 - 2mm; 3- gravel, 2 - 64mm; 4- cobble, 64 - 256mm; 5- boulder, > 256mm; 6- bedrock; 7- manmade

Bank Erosion: 0- not evident; 1- light fluvial; 2- moderate fluvial; 3- heavy fluvial / mass wasting

64. Comments (bank material variation, minor inflows, protection extent, etc.):

234 
65. Debris and Ice Is there debris accumulation?

67. Debris Potential $\underline{1}$ ( 1- Low; 2- Moderate; 3- High)

69. Is there evidence of ice build-up? 1

70. Debris and Ice Comments:
$(Y$ or $N)$ 66. Where? $\mathbf{Y}$

68. Capture Efficiency 2

(1- Upstream; 2- At bridge; 3-Both)

Ice Blockage Potential $\mathbf{N}$
(1-Low; 2- Moderate; 3- High)

(1-Low; 2- Moderate; 3- High) 1

\begin{tabular}{|l|c|c|c|c|c|c|c|c|}
\hline Abutments & $\begin{array}{c}\text { 71. Attack } \\
\angle \text { (BF) }\end{array}$ & $\begin{array}{c}\text { 72. Slope } \angle \\
\text { (Qmax) }\end{array}$ & $\begin{array}{c}\text { 73. Toe } \\
\text { loc. (BF) }\end{array}$ & $\begin{array}{c}\text { 74. Scour } \\
\text { Condition }\end{array}$ & $\begin{array}{c}75 . \text { Scour } \\
\text { depth }\end{array}$ & $\begin{array}{c}\text { 76. Exposure } \\
\text { depth }\end{array}$ & 77. Material & 78. Length \\
\hline LABUT & & $\mathbf{3 0}$ & $\mathbf{7 5}$ & $\mathbf{2}$ & $\mathbf{2}$ & $\mathbf{1}$ & $\mathbf{5 . 5}$ & $\mathbf{9 0 . 0}$ \\
\hline RABUT & $\mathbf{1}$ & $\mathbf{0}$ & $\mathbf{9 0}$ & & & $\mathbf{2}$ & $\mathbf{0}$ & $\mathbf{7 6 . 0}$ \\
\hline
\end{tabular}

Pushed: $L B$ or RB

Toe Location (Loc.): 0- even, 1- set back, 2- protrudes

Scour cond.: 0- not evident; 1- evident (comment); 2- footing exposed; 3-undermined footing; 4- piling exposed; 5- settled; 6- failed

Materials: 1- Concrete; 2- Stone masonry or drywall; 3- steel or metal; 4- wood

79. Abutment comments (eg. undermined penetration, unusual scour processes, debris, etc.):

$-$

1

The scour depth assumes a 1 ft. thalweg.

80. Wingwalls:

Exist? Material? Scour Scour Exposure Angle? Length? USLWW: Condition? depth? depth?

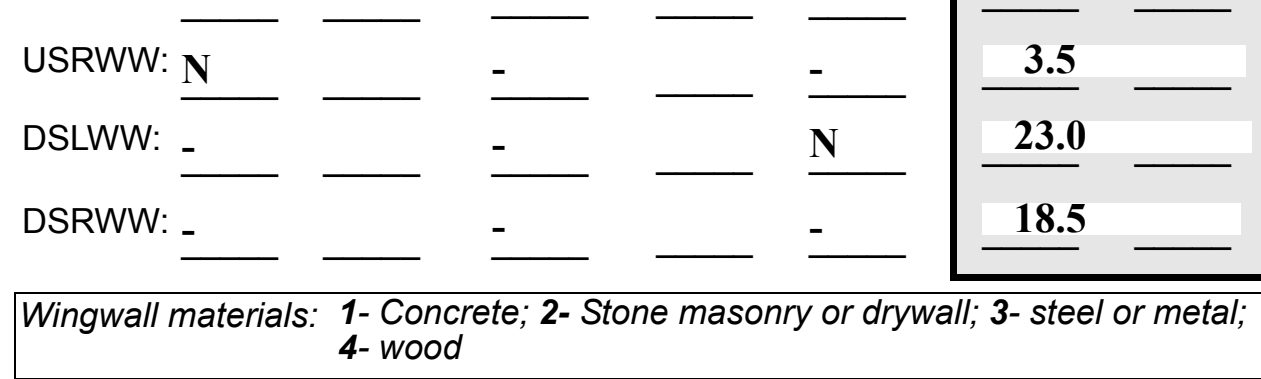

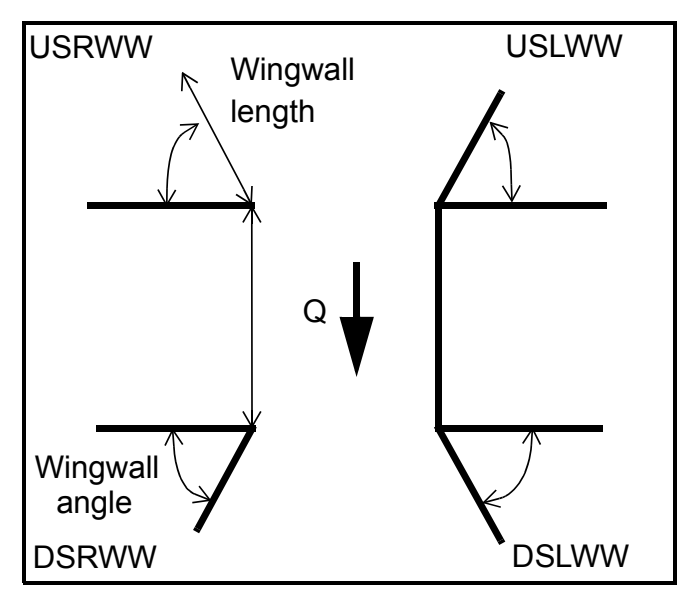

DSRWW

82. Bank / Bridge Protection:

\begin{tabular}{|l|l|l|l|l|l|l|l|l|}
\hline Location & USLWW & USRWW & LABUT & RABUT & LB & RB & DSLWW & DSRWW \\
\hline Type & - & - & N & - & - & - & $\mathbf{3}$ & - \\
\hline Condition & $\mathbf{N}$ & - & - & - & - & - & $\mathbf{1}$ & - \\
\hline Extent & - & - & - & - & - & $\mathbf{2}$ & $\mathbf{0}$ & - \\
\hline
\end{tabular}

Bank / Bridge protection types: 0- absent; 1- < 12 inches; 2- < 36 inches; 3- < 48 inches; 4- < 60 inches; 
83. Wingwall and protection comments (eg. undermined penetration, unusual scour processes, etc.):

-
-
-
-
-
-
-
-

\section{Piers:}

84. Are there piers? La (Y or if $N$ type ctrl-n pr)

\begin{tabular}{|l|l|l|l|l|l|l|l|}
\hline \multirow{2}{*}{$\begin{array}{l}85 . \\
\text { Pier no. }\end{array}$} & \multicolumn{3}{|c|}{ width (w) feet } & \multicolumn{3}{c|}{ elevation (e) feet } \\
\cline { 2 - 9 } & w1 & w2 & w3 & e@w1 & e@w2 & e@w3 \\
\hline Pier 1 & - & - & - & - & - & - \\
\hline Pier 2 & - & - & - & - & - & - \\
\hline Pier 3 & - & - & - & - & - & - \\
\hline Pier 4 & - & - & - & - & - & - \\
\hline
\end{tabular}

\begin{tabular}{|l|l|l|l|l|}
\hline Level 1 Pier Descr. & \multicolumn{1}{|c|}{1} & \multicolumn{1}{|c|}{2} & 3 & \multicolumn{1}{|c|}{4} \\
\hline 86. Location (BF) & rge & r the & & - \\
\hline 87. Type & boul- & wate & N & - \\
\hline 88. Material & ders & r. & - & - \\
\hline 89. Shape & are & & - & - \\
\hline 90. Inclined? & in & & - & - \\
\hline 91. Attack $\angle$ (BF) & front & & - & - \\
\hline 92. Pushed & of & & - & - \\
\hline 93. Length (feet) & - & - & - & - \\
\hline 94. \# of piles & the & & - & - \\
\hline 95. Cross-members & left & & - & - \\
\hline 96. Scour Condition & abut & & - & - \\
\hline 97. Scour depth & ment & & - & - \\
\hline 98. Exposure depth & unde & & - & - \\
\hline
\end{tabular}

LFP, LTB, LB, MCL, MCM, MCR, RB, RTB, RFP

1- Solid pier, 2- column, 3- bent

1-Wood; 2-concrete; 3- metal; 4- stone

1- Round; 2- Square; 3- Pointed

Y-yes; $N$ - no

$L B$ or $R B$

0- none; 1- laterals; 2- diagonals; 3- both

0- not evident; 1- evident (comment);

2- footing exposed; 3- piling exposed;

4- undermined footing; 5- settled; 6- failed 
99. Pier comments (eg. undermined penetration, protection and protection extent, unusual scour processes, etc.):

-
-
-
-
-
-
-
-
-
-

100.

\section{E. Downstream Channel Assessment}

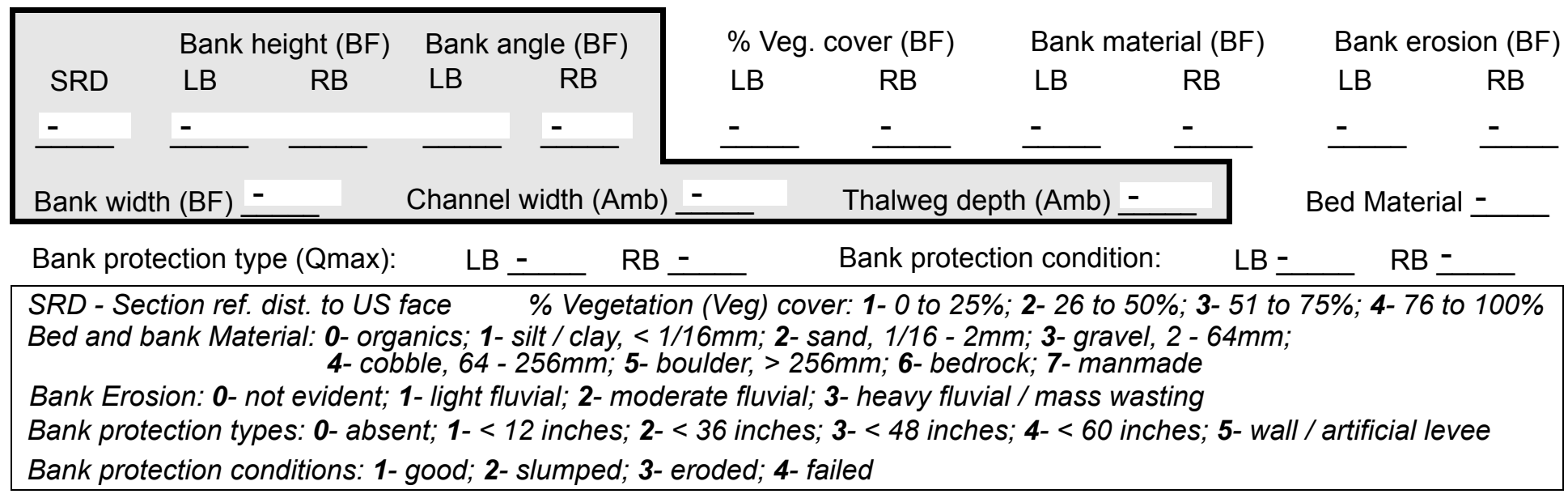

Comments (eg. bank material variation, minor inflows, protection extent, etc.):

-

NO PIERS

101. Is a drop structure present? $\mathbf{3}$ (Y or $N$, if $N$ type ctrl-n ds) 102. Distance: ___ feet 103. Drop: -_ feet 104. Structure material: 2 (1- steel sheet pile; 2- wood pile; 3- concrete; 4- other) 105. Drop structure comments (eg. downstream scour depth):

234

234

1

1

234

2 
Point bar extent: The feet $\underline{\text { ma }}$ (US, UB, DS) to teria feet $\underline{\text { lon }}$ (US, UB, DS) positioned the \%LB to ba Material: $\mathbf{n k}$

Point or side bar comments (Circle Point or Side; note additional bars, material variation, status, etc.):

s and in the channels has boulders buried underneath it. Beyond the exit cross section, the boulders and cobbles make up the channel banks. The left bank protection extends from $0 \mathrm{ft}$. DS to $38 \mathrm{ft}$. DS and also serves as road approach protection.

Is a cut-bank present? (Y or if $N$ type ctrl-n cb) Where? (LB or $R B)$

Mid-bank distance:

Cut bank extent: feet (US, UB, DS) to feet (US, UB, DS)

Bank damage: (1- eroded and/or creep; 2- slip failure; 3- block failure)
(eg. additional cut banks, protection condition, etc.): Bank damage: 1 (1- eroded and/or creep; 2- slip failure; 3- block failure)
Cut bank comments (eg. additional cut banks, protection condition, etc.):

$\mathbf{N}$

Is channel scour present? ( $Y$ or if $N$ type ctrl-n cs)

Mid-scour distance: NO

\section{F. Geomorphic Channel Assessment}

107. Stage of reach evolution $\mathbf{1 0 0}$ cour comments (eg. additional scour areas, local scouring process, etc.):

Are there major confluences?

Confluence 1: Distance $\mathbf{Y}$

Confluence 2: Distance 140 Enters on 215 Enters on $\underline{\mathbf{D S}}$ (LB or RB) ( $Y$ or if $N$ type ctrl-n mc) How many?

Type 65 (1- perennial; 2- ephemeral) Confluence comments (eg. confluence name):

Co

\section{5

(1)

S

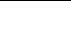

1- Constructed

2- Stable

3- Aggraded

4- Degraded

5- Laterally unstable

6- Vertically and laterally unstable 
108. Evolution comments (Channel evolution not considering bridge effects; See HEC-20, Figure 1 for geomorphic descriptors):

543

There is a shallower, narrower extension of this bar which reaches to $580 \mathrm{ft}$. DS.

Y

LB

160

80

DS

580

DS

1 


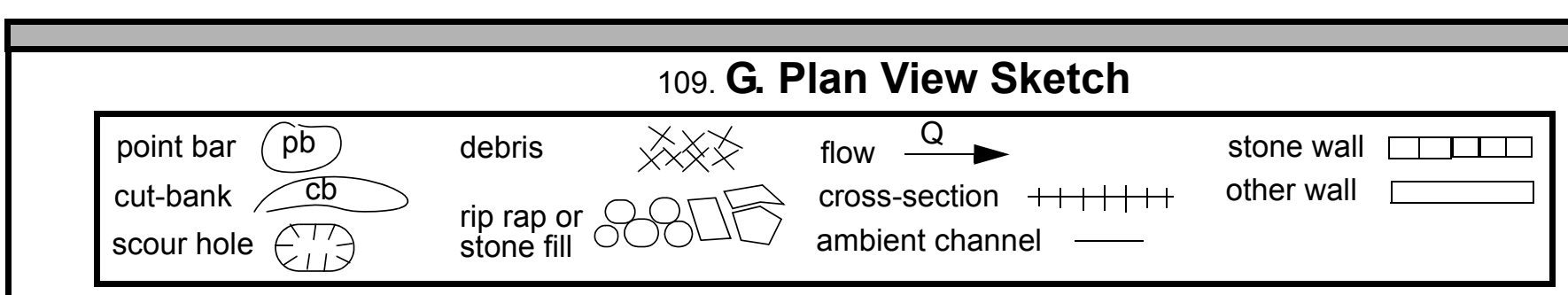


APPENDIX F:

SCOUR COMPUTATIONS 
SCOUR COMPUTATIONS

\begin{tabular}{|c|c|c|c|}
\hline Structure Number: ROCKTH00390041 & & Town : & Rockingham \\
\hline Road Number: $\quad$ TH 39 & & County: & Windham \\
\hline Saxtons River & & & \\
\hline Initials EMB & Checked: & SAO & \\
\hline Analysis of contraction scour, liv & -bed or $\mathrm{cl}$ & lear wate & \\
\hline $\begin{array}{l}\text { Critical Velocity of Bed Material } \\
\mathrm{VC}=11.21 * \mathrm{y} 1^{\wedge} 0.1667 * \mathrm{D} 50^{\wedge} 0.33 \text { with } \mathrm{S}\end{array}$ & $\begin{array}{l}\text { Converted } \\
=2.65\end{array}$ & to Engli & sh units) \\
\hline (Richardson and others, 1995, p. 2 & eq. 16) & & \\
\hline Approach section & & & \\
\hline Characteristic & $100 \mathrm{yr}$ & $500 \mathrm{yr}$ & other $Q$ \\
\hline Total discharge, cfs & 9100 & 13800 & 12130 \\
\hline Main Channel Area, ft2 & 1052 & 1468 & 1375 \\
\hline Left overbank area, ft2 & 0 & 0 & 0 \\
\hline Right overbank area, ft2 & 291 & 662 & 509 \\
\hline Top width main channel, ft & 112 & 116 & 115 \\
\hline Top width L overbank, ft & 0 & 0 & 0 \\
\hline Top width $\mathrm{R}$ overbank, ft & 72 & 184 & 81 \\
\hline D50 of channel, ft & 0.3393 & 0.3393 & 0.3393 \\
\hline D50 left overbank, ft & -- & -- & -- \\
\hline D50 right overbank, ft & -- & -- & -- \\
\hline y1, average depth, MC, ft & 9.4 & 12.7 & 12.0 \\
\hline Y1, average depth, LOB, ft & ERR & ERR & ERR \\
\hline $\mathrm{Y}^{1}$, average depth, $\mathrm{ROB}$, ft & 4.0 & 3.6 & 6.3 \\
\hline Total conveyance, approach & 150565 & 260914 & 242576 \\
\hline Conveyance, main channel & 134896 & 227959 & 205912 \\
\hline Conveyance, LOB & 0 & 0 & 0 \\
\hline Conveyance, ROB & 15669 & 32955 & 36665 \\
\hline Percent discrepancy, conveyance & 0.0000 & 0.0000 & -0.0004 \\
\hline Qm, discharge, MC, cfs & 8153.0 & 12057.0 & 10296.6 \\
\hline Ql, discharge, LOB, cfs & 0.0 & 0.0 & 0.0 \\
\hline Qr, discharge, ROB, cfs & 947.0 & 1743.0 & 1833.4 \\
\hline $\mathrm{Vm}$, mean velocity $\mathrm{MC}$, ft/s & 7.7 & 8.2 & 7.5 \\
\hline Vl, mean velocity, LOB, ft/s & ERR & ERR & ERR \\
\hline Vr, mean velocity, ROB, ft/s & 3.3 & 2.6 & 3.6 \\
\hline Vc-m, crit. velocity, MC, ft/s & 11.4 & 11.9 & 11.8 \\
\hline Vc-l, crit. velocity, LOB, ft/s & ERR & ERR & ERR \\
\hline Vc-r, crit. velocity, ROB, ft/s & ERR & ERR & ERR \\
\hline Results & & & \\
\hline Live-bed(1) or Clear-Water(0) Cont & action $\mathrm{ScC}$ & our? & \\
\hline Main Channel & 0 & 0 & 0 \\
\hline
\end{tabular}


Clear water Contraction Scour in MAIN CHANNEL

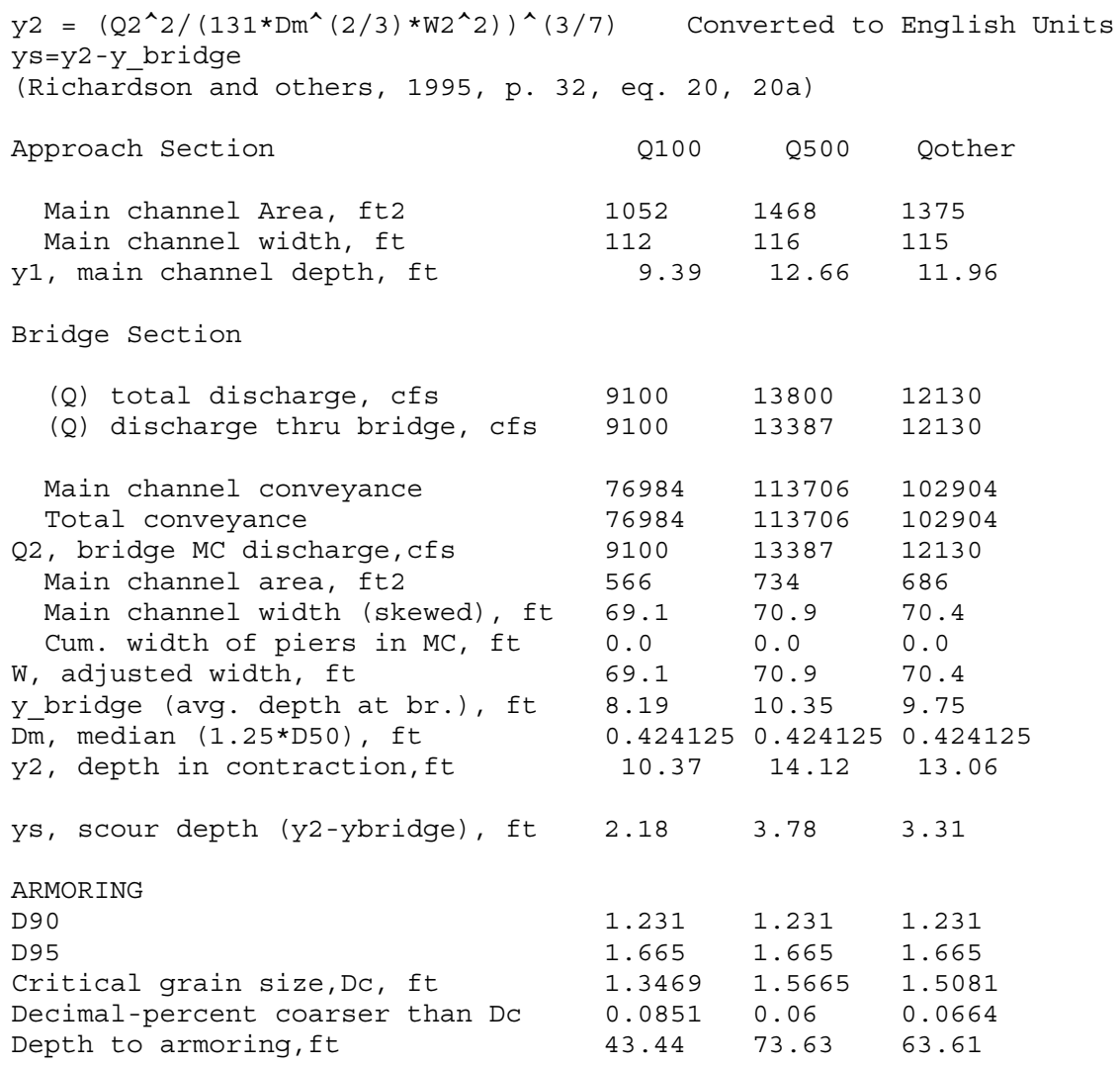




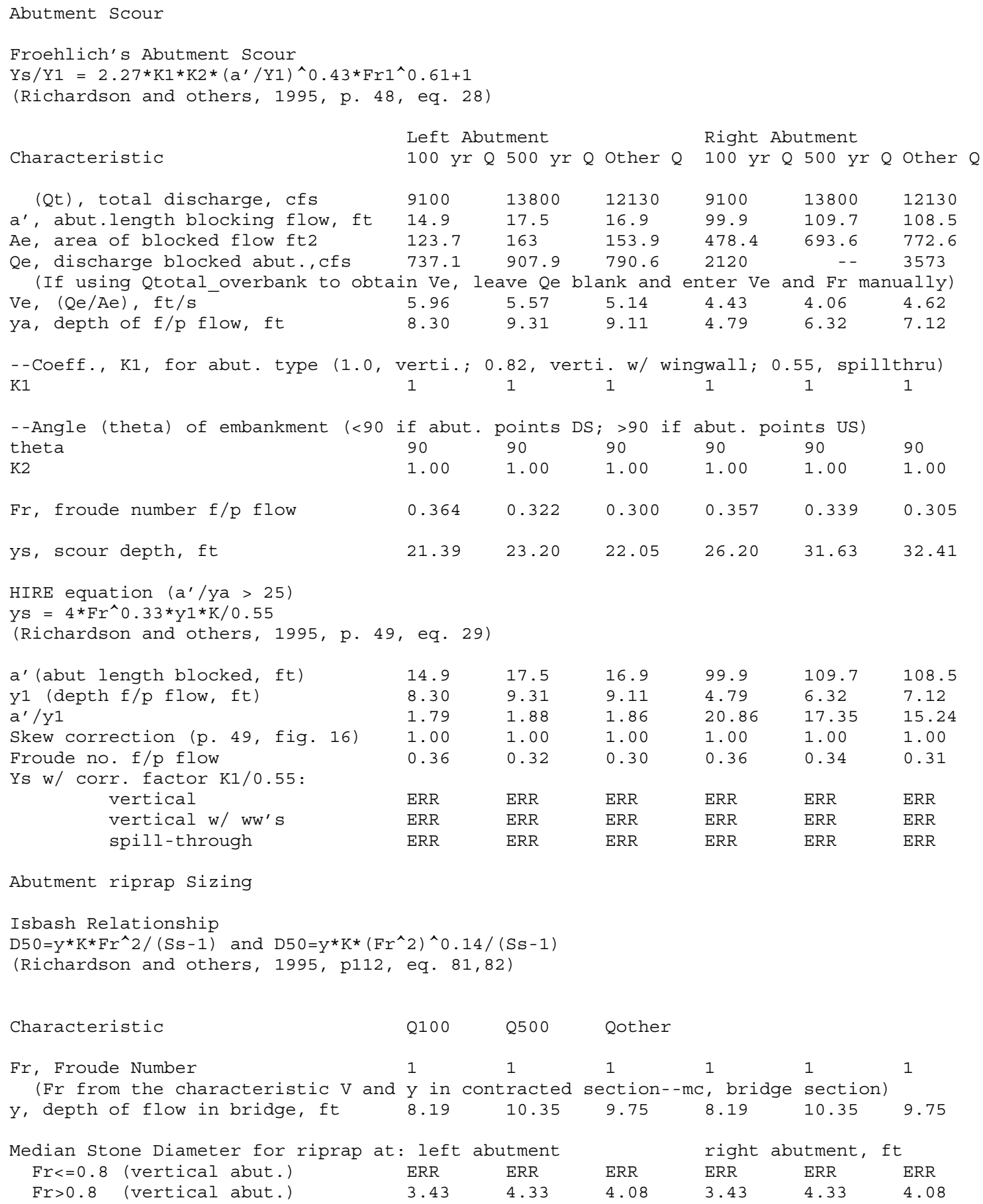

